\title{
Land Use Change and Effects on Water Quality and Ecosystem Health in the Lake Tahoe Basin, Nevada and California
}

By William Forney', Lora Richards', Kenneth D. Adams ${ }^{3}$, Timothy B. Minor ${ }^{3}$, Timothy G. Rowe', J. LaRue Smith', and Christian G. Raumann'

Open-File Report 01-418

2001

Any use of trade, product, or firm names is for descriptive purposes only and does not imply endorsement by the U.S. Government.

U.S. Department of the Interior

U.S. Geological Survey

U.S. Geological Survey, Menlo Park, California

${ }^{2}$ Raytheon, work performed under U.S. Geological Survey, Contract 1434-CR-97-CN-40274

${ }^{3}$ Desert Research Institute, University and Community College System of Nevada, Reno, Nevada

${ }^{4}$ U.S. Geological Survey, Carson City, Nevada 


\title{
Land Use Change and Effects on Water Quality and Ecosystem Health in the Lake Tahoe Basin, Nevada and California
}

\begin{abstract}
Human activity in the Lake Tahoe Basin has increased substantially in the past four decades, causing significant impacts on the quality and clarity of the lake's famous deep, clear water. Protection of Lake Tahoe and the surrounding environment has become an important activity in recent years. A variety of agencies, including the Tahoe Regional Planning Agency, Tahoe Research Group of the University of California at Davis, Desert Research Institute of the University and Community College System of Nevada, U.S. Geological Survey (USGS), and a host of State (both Nevada and California) and local agencies have been monitoring and conducting research in the Basin in order to understand how the lake functions and to what extent humans have affected its landscape and ecosystem processes. In spite of all of these activities, there remains a lack of comprehensive land use change data and analysis for the Basin.

A project is underway that unites the land cover mapping expertise of the USGS National Mapping Discipline with the hydrologic expertise of the Water Resources Discipline to assess the impacts of urban growth and land use change in the Lake Tahoe Basin. Three activities are planned over the next 3 years: (1) mapping the current and historic state of the land surface, (2) conducting analysis to document patterns, rates, and trends in urbanization, land use change, and ecosystem health, and (3) assessing the causes and consequences of land use change with regard to water quality and ecosystem health. We hypothesize that changes in the extent of urban growth and the corresponding increases in impervious surfaces and decreases in natural vegetation have resulted in severe impacts on ecosystem health and integrity, riparian zones and water quality over time. We are acting on multiple fronts to test this hypothesis through the quantification of landscape disturbances and impacts.
\end{abstract}

\section{INTRODUCTION}

\section{Background}

Situated in the Sierra Nevada Mountains, the Lake Tahoe Basin (fig. 1) has recently been recognized as an Outstanding Natural Resource for its water clarity and its depth; at 501 meters, it is the 2nd deepest lake in the United States and the $11^{\text {th }}$ deepest lake in the world. The lake is suffering from severe degradation of its natural resources as a result of human disturbance (Boughton and others, 1997; Byron and Goldman, 1987). Classified as an oligotrophic lake, cultural eutrophication is most clearly demonstrated by the trend of decreasing water clarity (Sullivan and others, 1996). The lake has averaged an annual reduction of 0.46 meters from a depth of 32 meters in 1968 to 21.5 meters in 1995 (TRPA, 1996). In addition to the suspended sediments in the lentic regions, water clarity is a function of the primary productivity of the lake. As primary productivity is a function of nutrient loading, an overall decrease in water quality (which can be a proxy for sediment and nutrient inputs) can lead to a decrease in water clarity.

California, and the Sierra Nevada in particular, are experiencing rapid population growth that shows no signs of slowing. Between 1970 and 1990, population in the region doubled with more than 40 percent of the growth occurring in just four counties that encompass the Tahoe Basin: Washoe, Douglas, Placer, and El Dorado. In the City of South Lake Tahoe, the population increased from 12,921 in 1970 to 22,850 in 1998 (CDOF, 1999). For the Sierra Nevada as a region, the population is projected to triple between 1990 and 2040 (Duane, 1996), with a significant proportion of the growth occurring in and around the Tahoe Basin. Population growth results in urbanization, which directly and indirectly affects natural systems and landscape processes. Already this growth has exacerbated the tension between people and the environment. 


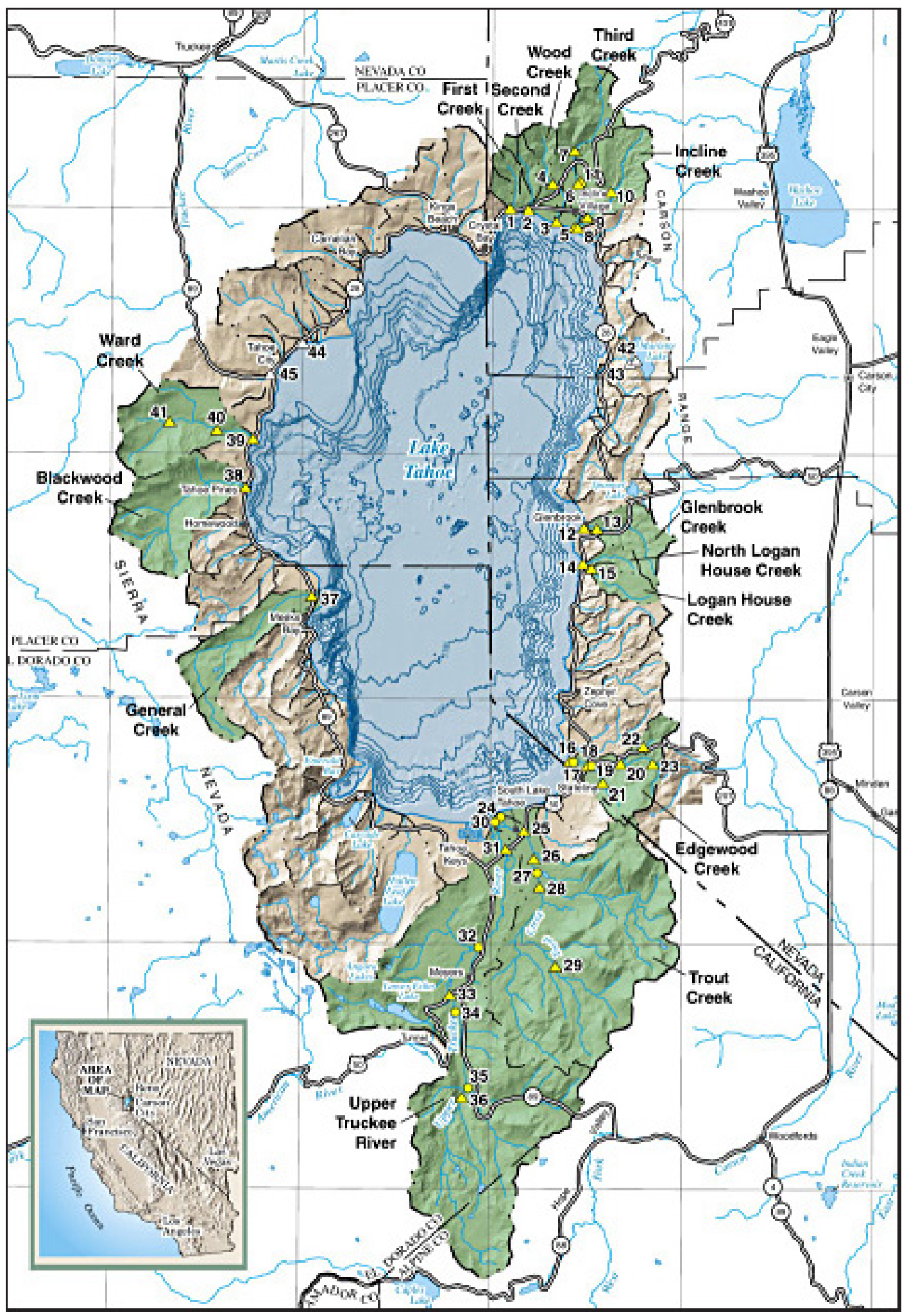

Figure 1. Map of Lake Tahoe Basin showing tributary watersheds and locations of Lake Tahoe Interagency Monitoring Program (LTIMP) stations. 
Rapidly growing counties, and particularly those emerging from rural to urban, frequently lack the resources to adequately monitor and forecast the impacts of land development on biologic, hydrologic, and social resources. To further complicate monitoring and forecasting in the Tahoe Basin, the proximity of the Tahoe Basin to the Sacramento Valley and San Francisco Bay Area results in significant tourist population growth because of the variety of available recreational opportunities (such as casino gaming, skiing, golfing, water sports, hiking, and camping). More than 8 million people live within a few hours drive to Lake Tahoe (Boughton and others, 1997). Although the Basin supports a year-round population of approximately 60,000, on any given weekend the population can swell to over 300,000, with an annual total of 22 million visitors (McCarthy, 1997).

This rapid population growth has resulted in a variety of impacts on the Tahoe ecosystem. Specifically, studies have documented the correlation between human disturbance, exponentially increasing algal productivity, and corresponding decreasing water clarity in Lake Tahoe (Byron and Goldman, 1989). A variety of causes are recognized as drivers of this cultural eutrophication in the Basin, including the loss of wetlands, erosion due to development on steep slopes, discharge from septic and sewer systems, and airborne discharge from vehicles and wood-burning stoves. Increased sediment and nutrient loading is understood to be a primary factor in reduced water quality in tributaries, thus reducing water clarity in the lake (Boughton and others, 1997).

Alteration of the landscape and other human-caused disturbances has been shown to be important factors affecting mass transport (loading) of principal plant nutrients (nitrogen and phosphorus) and sediment to the lake (Loeb, 1988). The increase of bioavailable nutrients over time is suspected as a principal cause for the increase in algal growth in the lake, with a concomitant decrease in water clarity. Data collected by University of California at Davis scientists show that the clarity of the lake, as measured by Secchi disk, has been declining at a rate of over 1 foot per year (Goldman, 1988). Furthermore, because of its physical configuration and mean residence time of 700 years for water (TRPA, 1996), Lake Tahoe effectively traps inputs of chemical constituents, particularly nitrogen and phosphorus, making them potentially available for biological recycling within the lake or for entrainment in sediments. Sediment in tributary runoff is known to reduce the clarity of receiving waters and act as a carrier in the transport of certain nutrients, particularly phosphorus and iron.

\section{Description of the Study Area}

Located in the Sierra Nevada Range, the Lake Tahoe Basin is part of the Truckee River watershed that occupies parts of both eastern California and western Nevada (fig. 1, inset). The headwaters of the Truckee River system originate in the Sierra Nevada above Lake Tahoe. Sixty-three watersheds covering a land area of 314 square miles (813 square kilometers) flow into the lake (fig. 1). The lake itself covers 192 square miles (497 square kilometers). The lake is a natural feature that has been converted to a reservoir through the installation of a small dam at the lake's outlet on the western shore at Tahoe City. From this outlet, the waters of Lake Tahoe flow north through the town of Truckee and then northeast to the terminus of the Truckee River system at Pyramid Lake, NV (CDWR, 1991; Rowe and Allander, 2000).

Vegetation in the Tahoe Basin is primarily coniferous forest with alders, aspen, and willows common along the stream zones (Cartier and others, 1993). Precipitation occurs mostly in the form of winter snow and ranges from 25 inches to more than 60 inches, with a general decrease from west to east (Twiss and others, 1971).

\section{Permanent Human Settlement in the Lake Tahoe Basin}

Although Native Americans inhabited the Sierra Nevada for thousands of years prior to European arrival, not until the middle of the 19th century did permanent human settlement commence and the impacts of major land use change begin to unfold on the land. The Washoe peoples of the eastern Sierra Nevada and western Nevada hunted, fished, gathered, and traded throughout the Tahoe Basin and surrounding areas, but their population numbers and settlement patterns were not as land-altering as the European-Americans who arrived during the middle of the 19th century丩(Richards, 1999; Duane, 1996).

\footnotetext{
${ }^{1}$ For an in-depth discussion of the human history of the Lake Tahoe Basin refer to Susan Lindstrom's chapter in the Lake Tahoe Watershed Assessment titled "A Contextual Overview of Human Land Use and Environmental Conditions." (Chapter 2, Volume 1 published in 2000 by U.S. Department of Agriculture Pacific Southwest Research Station)
} 
Since 1844, overland migrants and expedition parties had used the north-central Sierra Nevada region surrounding the Tahoe Basin as a transportation corridor for westward movement to California (Howard, 1998). For nearly 20 years, various wagon roads were constructed to allow gold seekers and other travelers over the formidable mountains; however, permanent settlement in the central Sierra Nevada was nonexistent (Hinkle and Hinkle, 1997). Not until the economic incentives associated with construction of the first transcontinental railroad arrived did permanent settlement begin (mid-1860s) (TDHS, 1994).

Development in the form of logging operations initially commenced to supply the construction of the Central Pacific. A short time later, rapid expansion of silver mines of the Comstock Lode located at Virginia City fueled the expansion and stability of the logging operations (Richards, 1999). To support this extractive industry, small towns appeared throughout the Basin to house and supply mill workers. The permanent population of the Tahoe Basin and the surrounding north central Sierra Nevada was very modest in size even though the extent of its logging operations was not. Throughout the 19th century, lumbering and associated industries were strong and profitable (Irons, 1885; NDWP, 1997). Construction of the railroad not only created a local timber market, but its transcontinental ties enabled regional timber products to be supplied throughout the West and beyond (Wilson, 1992).

Mining activities at Virginia City declined rapidly in the late 1880s (Goldstein, 1988), causing logging operations to slow somewhat, but ultimately logging remained a prosperous business through the end of the century (TDHS, 1994). By 1910, the large and abundant forests that blanketed the north-central Sierra Nevada were largely exhausted from almost nonstop logging operations. In California and other parts of the United States, a land and forest preservation movement took hold. As a result, the Lake Tahoe area, in addition to forested lands throughout the northern Sierra Nevada, was placed into National Forests (Omarzu, 1999). As logging slowed, permanent population growth also slowed and even decreased. The railroad also experienced decline as improved roads and the personal automobile became available and affordable (Richards, 1999).

Tourism had been a part of the Tahoe economy since the first years of settlement in the mid-1860s. During the railroad era (1860s-1920s), magazines and newspapers promoted the mountain scenery and recreation activities on a regular basis (Howard, 1998; TDHS, 1994). Rail accessibility provided by the Central Pacific and feeder lines tied Sacramento and San Francisco area communities to the Tahoe Basin. During the 1930s and 1940s, the Tahoe area experienced the beginnings of a sustained increase in tourism as gaming was legalized in Nevada (NDWP 1997) and winter carnivals and ski tournaments were held in towns in and around the Basin (TDHS, 1994). Roads were improved, including the Lincoln Highway? the Nation's first transcontinental highway (which traveled mostly alongside the same route as the Central Pacific) and the use of snow removal equipment commenced, keeping roads cleared during the winter months (Placer County Chamber of Commerce and Auburn Chamber of Commerce, written commun., 1952). The mood of an era heavily dominated by the World Wars and the Great Depression caused a partial delay in tourism until the middle to late 1940s when service people returned home from war and disposable incomes increased (Richards, 1999).

Following the Second World War, California emerged as one of the strongest economic forces in the world. Much of the State's recreation and tourism to take a permanent and long-lasting hold on the Tahoe Basin and the Sierra Nevada in general (Richards, 1999). One of the most significant events in the Basin's tourism development was the selection of Squaw Valley (on the northwest side of the Basin between Truckee and Tahoe City) for the 1960 Winter Olympics. The Olympics promoted the area in a previously unparalleled fashion (Scott, 1957). Some \$20 million (Lantis and others, 1989) in State expenditures and several million in private monies were spent to construct hotels, population benefited from this prosperity, especially in the San Francisco Bay Area (Bank of America, 1996; Wollenberg, 1985). The growth of personal prosperity, combined with infrastructure improvements, set the stage for restaurants, shops, and a host of other service facilities. Transportation improvements were funded too, which resulted in the reconstruction of the old highway into a new interstate (I-80), enabling the traveler to journey from San Francisco to the Sierra Nevada in approximately 4 hours (NDWP, 1997).

\footnotetext{
${ }^{2}$ The Lincoln Highway was later called US Highway 40. When Interstate 80 was constructed in the 1960s, much of US Highway 40 was widened and straightened and renamed Interstate 80. A 30-mile stretch of the original route of the Lincoln Highway/US 40 still exists independently of Interstate 80 between Cisco Grove and Truckee, CA, as Donner Pass Road.
} 
With the necessary transportation infrastructure in place and Northern California's growing population and economic prosperity, tourism activity in the Tahoe Basin, as well as the greater Reno-Tahoe-Truckee area, has continued to rapidly increase since the 1960s. Permanent population numbers have surged in the last 30 years, several ski areas have been constructed or expanded, and numerous residential and commercial operations have been built. Seasonal home and recreational cottage construction has also accelerated, causing dramatic changes to the local landscape (Richards, 1999). The Tahoe Basin now has the largest permanent population in the entire Sierra Nevada (more than 60,000 permanent residents). The tourist economy, which had previously been characterized by uneven seasonal activity (Lantis and others, 1989), has evened out; winter and summer are no longer the only seasons experiencing heavy tourist traffic. Air transport has expanded, as have the marketing and promotion of events such as ski competitions, golf tournaments, mountain biking challenges, rodeos, and so on (Richards, 1999).

As the area has grown to accommodate more tourists and a greater permanent population, various concerns over air, water, and other natural resources have followed. As Rothman (1998, p. 155) states, "The inherent problem of communities that succeed in attracting so many people is that the presence of those very people [has the potential to] destroy the cultural and environmental amenities that make the place unique."

As the Lake Tahoe Basin is a tourist- and recreation-driven economy, the tension between a healthy ecosystem and a healthy economy is present in every land use decision. Understanding the connection between landscape changes, water quality, and ecosystem processes is essential to bringing an ecological and sustainable perspective to public policy decisions that affect local communities.

\section{WATER QUALITY}

During the 1980s, Tahoe Research Group (TRG) at the University of California at Davis researchers related the level of land disturbance in sampled basins to water quality in these basins (Byron and Goldman, 1989). They found increased water quality degradation with increased levels of land disturbance. In 1998, TRG researchers correlated historic land disturbance with sedimentation rates through the analysis of sediment cores. The analysis results of five sediment cores from Lake Tahoe showed that the average mass sedimentation rate during the Comstock logging era (1860 to 1900) was $0.043( \pm 0.011) \mathrm{g} / \mathrm{cm}^{2} / \mathrm{yr}$. By comparison, the average mass sedimentation rate for the recent period (1970 to 1990) was $0.027( \pm 0.006) \mathrm{g} / \mathrm{cm}^{2} / \mathrm{yr}$. Both these rates are significantly higher than the average sedimentation rate of $0.009( \pm 0.004) \mathrm{g} / \mathrm{cm}^{2} / \mathrm{yr}$ that occurred during the intervening period (1900 to 1970). The fact that mass sedimentation rates and biogenic silica flux decreased shortly after the logging disturbance ended is testimony to a rapid landscape stabilization with second-growth forest. It also indicates that Comstock logging produced a pulse disturbance. By contrast, the disturbance from urbanization, in particular roads and other impervious surfaces, could persist as a chronic perturbation for a considerable time (Reuter and others, 1997).

The Tahoe Regional Planning Association (TRPA), the USGS, and the TRG are monitoring sediment from streams and nutrient loads from both the streams and ground water aquifers in the Basin. An assessment of the water quality impacts in the Basin due to land use change will use the archive of scientific data on stream water quality and discharge, and ground water levels, quality, and flow paths collected as part of the Lake Tahoe Interagency Monitoring Program (LTIMP). Various historical data related to the hydrologic and limnologic properties of ground and surface water in the Basin have been collected.

Using LTIMP data and other ancillary sources, Rowe and Allander (2000) found that ground water contributed 40 percent of streamflow in the Upper Truckee River to Lake Tahoe, and in Trout Creek ground water accounted for 5 percent. Furthermore, nitrate, ammonia, and orthophosphorus concentrations were found to be higher in ground water samples than in surface water samples (Rowe and Allander, 2000). In Ward Valley, ground water accounted for 16 percent of the creek's volume and 10 percent of the total precipitation within the catchment. More importantly, with respect to the surface flow, ground water contributed 49 percent of the total nitrate and 44 percent of the total soluble phosphorous loads to Lake Tahoe (Loeb and Goldman, 1979). Because of these analyses of ground water influence in various regions in the Tahoe Basin, it is important to acknowledge the need to incorporate subsurface processes of nutrient loading. 
From the analysis of LTIMP, it has been found that 75 percent of annual stream loading of phosphorous occurs during spring snowmelt. For phosphorous concentrations, 45-88 percent occurs as particulate phosphorous occluded to silt and clay, dissolved organic phosphorous comprises 6-42 percent, and phosphate accounts for 6 percent to 16 percent (Hatch, 1997). Because of the correlation of discharge, phosphorous load, precipitation, basin area and slope, and impervious cover; Hatch hypothesized that the human impact on stream ecology was likely, particularly during high precipitation years.

Many projects are documented in the literature that assess impacts on water quality and water-based ecosystems caused by agricultural land use practices (Brakebill, 2001; Martin and others, unpublished presentation, 1999; Bradbury and Van Metre, 1997; Mattikalli and Richards, 1996). Although minimal agricultural practices persist in the Basin, fertilizers used on lawns and golf courses mimic some components of agricultural practices. Furthermore, the rationale of these studies and the techniques they adopt to link certain land uses with impacts on ecosystems afford insight to techniques that can be adapted to the scenario in the Tahoe Basin.

Overall, water quality assessment is often viewed as an integrated environmental indicator of ecosystem function and stress (Berka and others, 1995). One of the present needs in scientific investigations is to link together the disparate facts and analyses such as the ones previously mentioned. This is especially pertinent in systems such as Tahoe that are balancing between natural preservation and human utility. Understanding how the Lake Tahoe Basin and watersheds such as the Upper Truckee River and Trout Creek have evolved through time and what changes have occurred on these systems is critical for placing water quality studies into context. Furthermore, this understanding provides valuable information for present and future restoration efforts along these systems and throughout the Tahoe Basin.

\section{Ecosystem Health}

One way to analyze the health of the Lake Tahoe ecosystem is to assess well-documented hydrologic indicators, such as water quality. From an ecologic and biologic perspective, another way to characterize ecosystem health is through ecosystem integrity. The form or integrity of an ecosystem is directly linked to its function, and its function is directly related to its health. In addition to the previous section on water quality, the following discussion will further clarify this by demonstrating how different land cover types can be sources and/or sinks of nutrients and sediments that are transported through a hydrologic system.

Using an inorganic nitrogen budget in Ward Valley, Coats and others (1976) found that well-developed conifer stands can assimilate almost all of the inorganic nitrogen, but not if they have been disturbed. Furthermore, they found that nitrification is more related to the carbon-nitrogen ratio and stand basal area than to the $\mathrm{pH}$ of litter decay. They also found that mountain alder stands (Alnus tenuifolia) release nitrate to soil water in the fall and early winter as they enter into senescence. As another example of the interdependence between land cover types and ecosystem function, ground water nitrogen fluxes have been found to be greatest in alder-rich systems and lowest in grassmeadow land cover types of riparian zones (Merrill, 2001). Furthermore, soils in the Sierra Nevada have been found to be sinks for ammonium, hydrogen, and sulfate (Williams and Melack, 1991).

Disturbances to Stream Environment Zones (SEZ) have shown to have deleterious impact on an ecosystem's ability to function. Riparian ecosystems can be categorized by their nutrient dynamics and water quality effects through processes that exist in the stream channel and the hyporehic zone (Merrill, 2001). SEZs and riparian buffers can trap sediment and uptake nutrients, a function that is compromised when they are drained, altered, or encroached upon (Weller and others, 1997). Furthermore, the TRPA code of ordinances forbids development in SEZs (TRPA, 1999).

Steep slopes and erodible soils are also biogechemically linked to ecosystem dysfunction; disturbances to steep slopes and erodible soils have been shown to increase nitrate, total and soluble phosphorous, and suspended sediment (Byron and Goldman, 1989). Many steep, erodible slopes have been disturbed by road development around the Basin.

In addition to land cover types, different types of land uses have been tied to impacts on water quality and ecosystem health. Historically, because of spray disposal of secondary-treated sewage effluent, Heavenly Valley Creek (a Trout Creek tributary) was enriched in nitrate. Furthermore, the remnant disconnected septic tanks and fertilizers applied to lawns and golf courses can contribute to nitrate enrichment in shallow ground water around South Lake Tahoe (Coats and Goldman, 1993). 


\section{Role of Impervious Surfaces}

The intensity of land uses is an important characteristic in assessing change and impacts (Berka, and others, 1995). One way to assess land use intensity is to look at the imperviousness of the surface of the landscape. Impervious surfaces (paved or built-upon areas) deny or inhibit the infiltration of water into the soil underneath. Impervious surfaces may vary substantially with land use and stage of urban development (Cablk and Minor, 2001); however, in the urban environment, most impervious surfaces are either transportation (roads, sidewalks, parking lots, and so on) or rooftops (residential, commercial, industrial, and so on) (Sleavin and others, 2000). Impervious cover estimates for anthropogenic surfaces are incorporated directly into sediment-loading models and used in threshold analysis by TRPA, the principal regulatory agency in the Basin (Cablk and Minor, 2001).

The mapping of impervious ground cover is important for understanding the transport of pollutants, in particular, into water bodies (Prisloe and others, 2001; Brun and Band, 1999; Civco and Hurd, 1997). Various researchers with Project NEMO at the University of Connecticut have conducted numerous studies related to land use, impervious surfaces, stormwater runoff, and water quality (Prisloe and others, 2001; Sleavin and others, 2000; Civco and Hurd, 1997). Because these researchers have conducted such extensive and varied projects related to land use change and water quality, their project will be consulted and used as a framework for our own work.

Forney's (1999) earlier research on erosion and land use in the Upper Truckee watershed demonstrates that the human need for housing, infrastructure, commerce, and recreation has altered the rainfall-runoff and erosion dynamics of the landscape. Urbanization truncates the flowpath of precipitation as ground water systems are not recharged and the water that enters the system circulates through the watershed more swiftly and with greater volume (Arnold and Gibbons, 1996). The land cover disturbance and its spatial pattern alter the vegetative communities and increase nutrient loading and sedimentation (Binford and Buchenau, 1993). Furthermore, depending on the infiltration capacity of the soil, impervious coverage increases the volume and potential erosive capacity of the overland runoff, gully erosion, and channel incision, particularly in areas sensitive to disturbance, such as erosive soil types, steep slopes, and riparian zones (Binford and Buchenau, 1993; Arnold and Gibbons, 1996; McMahon and Cuffney, 2000; Prisloe and others, 2001).

As part of the impervious surface component of the land use mapping, special attention will be paid to temporal road mapping in the Tahoe Basin. Previous studies conducted as part of the USGS Urban Dynamics Research Program have demonstrated the importance of studying the temporal road network to understand the regional implications of urban growth (Clark and others, 1996; Bell and others, 1995). A historical understanding of road construction and the progression from unpaved roads to highways is necessary to properly examine the patterns, rates, and trends of urbanization in the Tahoe Basin. Roadways are significant because of their ability to move people between places, and in the Tahoe Basin, transportation history and evolution are a significant part of the area's historical geography. Beyond its human geographical component, the temporal road mapping will focus on impervious qualities and the relationship of roads to landscape fragmentation.

As part of the Sierra Nevada Ecosystem Project, McGurk and Davis (1996) used temporal land use and road mapping to assess the hydrologic effects of 50 years of land management practices in the Camp and Clear Creek watersheds. Their study concluded that disturbances to the natural systems have been caused primarily by logging, road building, and residential development. In a similar fashion, the transportation features in the Upper Truckee River and Trout Creek watersheds will be mapped to assess impacts on water clarity and quality, as well as ecosystem health.

\section{Ongoing and Related Activities}

The project builds upon and complements research activities both within and outside the USGS. Using geographic analysis and spatially referenced data in a geographic information system (GIS) environment, the USGS Center for Science Policy (CSP) conducts research to integrate multidisciplinary science to inform social issues and policy questions. Research focuses on ways to translate science and synthesize disciplines into quantifiable metrics, efforts that involve the use and weighing of economic values, natural resource processes, and statistical analyses.

The project complements another CSP research project; in conjunction with the Desert Research Institute (DRI), the CSP is assessing the effectiveness and utility of the TRPA's land use system. Furthermore, they are in the process of developing the Tahoe Constrained Optimization Model for TRPA to inform growth and restoration policy decisions, as well as conduct "what if" scenarios of optimal suites of development and preservation based on 
regulated load goals (Bernknopf and Forney, 2000). These load goals are motivated by nonpoint Total Maximum Daily Loads (TMDL) implemented through the U.S. Environmental Protection Agency (EPA) (Tracy and others, 2000). Part of this research depends on an accurate assessment of land use and land cover for commercial, residential, industrial, and undeveloped parcels. Such an assessment would aid the valuation of nonmarket goods for economic models, allow the incorporation of additional water quality models, and improve the monitoring of TRPA's impervious coverage threshold.

The USGS Urban Dynamics Program analyzes land use change in urban environments with a focus on understanding causes and consequences. Activities involve describing the current and historical land surfaces, monitoring changes to the landscape, understanding the processes causing change, predicting the consequences of change, and improving the application of scientific information with regard to policymakers, scientists, public trust managers, and land use management agencies. Earlier studies have demonstrated the utility of temporal and historical mapping, geographic analysis, and growth modeling (Acevedo and others, 1999; Clarke and Gaydos, 1998; Clarke and others, 1997; Acevedo and others, 1996; Crawford-Tilley and others, 1996; Clark and others, 1996; Bell and others, 1995; Kirtland and others, 1994). The proposed work enhances the USGS Urban Dynamics Program by addressing integrated science issues and societal concerns. Specifically, this project addresses societal concerns outlined as critical for research: urban growth and quality of life, ecological integrity and ecosystem health, water quality and quantity concerns, and increased accessibility to scientific information for education and decisionmaking purposes.

This work enhances and leverages funding to a variety of Tahoe Basin activities underway through local, State, and Federal agencies. Notable projects include ongoing water quality research, DRI's impervious surface mapping and shorezone change studies, U.S. Forest Service's forest and roads mapping projects, TRPA's SEZ mapping, the City of South Lake Tahoe's Trout Creek Restoration Project, and the ones mentioned below.

The Northern Nevada District Water Resources Office of the USGS has ongoing surface and subsurface water monitoring and research activities. The district office has been actively involved in numerous water quality studies in the Lake Tahoe Basin and oversees the coordination of Federal activities in the Basin (Rowe and Allander, 2000; Rowe, 1999; Smith and others, 1999; Rowe, 1998; Rowe and Stone, 1997; Boughton and others, 1997). Work is currently underway on a report titled, "Estimating Loads, Yields, and Trends of Nutrients, Suspended Sediment, and Streamflow from Developed and Undeveloped Watersheds Tributary to Lake Tahoe, California- Nevada, 1980-98." As part of that study, nested estimates of sedimentation loading through Incline Creek have been conducted (Tim Rowe, WRD Carson City, personal communication, March 28, 2001). One of the problems faced in this study is a paucity of accurate land use data for the past and present.

Recognizing that rapid population growth presents many social and natural resource challenges, collaborators at the Sierra Business Council are currently involved in projects that look to accommodate growth while maintaining the environmental quality and small town appeal that lure vast numbers of visitors to the Sierra Nevada. Using indicators of natural, financial, and social capital, the Sierra Business Council developed the Sierra Nevada Wealth Index in an attempt to gain an integrated understanding of the state of the region (Sierra Business Council, 2000, 1999, 1996). Specifically, their Town Planning Services unit is engaged in long range urban planning for 21 counties in the region. The mapping and analysis results conducted as part of this project will serve as critical input to their planning and education goals.

\section{RESEARCH APPROACH}

The general approach to the project is threefold: (a) conduct temporal high-resolution land cover mapping and classification with historical digital orthophoto quadrangles (HDOQ) and IKONOS satellite imagery; with that information (b) correlate land use and land cover (LULC) dynamics to changes in water quality, and (c) assess the current state of ecosystem health in the study area. The second and third tasks are somewhat interdependent and will be conducted once the first task is completed (Chart 1). 
Chart 1. Schematic of research approach.

\begin{tabular}{|l|l|l|}
\hline IKONOS $\left(25 \mathrm{~km}^{2}\right.$ scene $)$ & HDOQs (pilot watersheds) & Fieldwork \\
\hline - Obtain imagery. & - Produce HDOQs. & - LULC class definition \\
- Classify impervious cover. & - Produce temporal LULC datasets. & - Accuracy assessments \\
- Classify natural cover. & - Temporal transportation layer & - Clarify mixed pixel problems. \\
\hline
\end{tabular}

\begin{tabular}{|c|c|}
\hline \multicolumn{2}{|c|}{ ANALYSIS } \\
\hline \multicolumn{2}{|c|}{ Landscape Structure } \\
\hline \multicolumn{2}{|c|}{$\begin{array}{c}\text { Investigate and define metrics. } \\
\text { Assess the integrity of the landscape. }\end{array}$} \\
\hline Water Quality & Ecosystem Health \\
\hline $\begin{array}{l}\text { - Assess the change in two hydrographs. } \\
\text { - SCS Curve Number analysis. } \\
\text { - Export coefficient model. } \\
\text { - Regress class metrics to water quality } \\
\text { parameters. }\end{array}$ & $\begin{array}{l}\text { - Change in class and landscape metrics, } \\
\text { fractal dimension. } \\
\text { - Change in SEZs and riparian patches. } \\
\text { - Metapopulation dynamics and corridors. } \\
\text { - Human and naturally induced disturbance } \\
\text { regimes. }\end{array}$ \\
\hline
\end{tabular}

Year 1 of the project (FY2001) is focused on conducting these activities in a pilot area in the southern part of the Tahoe Basin. Specifically, efforts are concentrating on the administrative needs of the project team, creating the HDOQs, obtaining related datasets, such as GIS coverages and LTIMP data, gathering more literature and techniques of analysis, analyzing existing LULC classification systems, constructing a LULC cover classification system appropriate to the needs of the project, and conducting field work to help with classification efforts. In subsequent years, we will conduct analysis for the pilot area and expand the mapping, correlation of datasets, and analysis activities to the rest of the Basin.

Specifically, the first part of the project will map land cover and use for 1940, 1969, 1987, and 1998 using HDOQs. A test area for 2000 will also be mapped from IKONOS satellite imagery. We will assess the benefits of using HDOQs versus high-resolution satellite imagery (compare costs, ease of acquisition, and utility in deriving land cover and use information). In addition, we will test the utility of quantitative landscape ecology metrics that characterize the temporal land cover/use data. The statistics derived from the imageries with a software package called FRAGSTATS will be used for three purposes: (1) track how the structure and pattern of the landscape has changed over time, (2) test the ability to link those statistical changes to significant changes in the water quality parameters of the LTIMP data, and (3) assess how those changes have affected the proper functioning condition of the ecosystem.

An analysis of historical and contemporary land cover will provide useful metrics and information on the patterns, rates, and trends of change. Consideration of the rates and directions of land use change will provide an understanding of impacts on natural systems. Consequently, the development of quantitative metrics that characterize LULC data is essential. Rates and directions of change in natural systems, often the result of human activity, are a critical aspect to quantify and link to other parameters of ecosystem sustainability (Elliot-Fisk and others, 1996). 


\section{Hypotheses of Research}

To understand landscape change in the Tahoe Basin, we must understand the current state of the land, the forces of change that have created the current landscape, and the causes and consequences of the change. Overall, the proposed project will examine 5 key integrated hypotheses:

1. Changes in impervious cover have changed the form of the hydrographs for watersheds of the Lake Tahoe Basin.

2. Changes in natural land cover types have changed the water quality for the watersheds of the Lake Tahoe Basin.

3. Riparian areas tend to be preferentially urbanized, and SEZs are deleteriously affected.

4. Ecosystem health has been deleteriously affected by land cover change and increased impervious cover.

5. IKONOS data can be used to make finer distinctions between land use and land cover types than DOQ imagery techniques.

\section{Potential Criteria for the Validation of Hypotheses}

1. For watersheds with LTIMP streamflow gages, changes in impervious cover are correlated with changes in the form of the hydrograph.

2. Changes in the nutrient or sediment loading over time in watersheds with LTIMP water quality gages are statistically correlated to historic landscape patterns.

3. Evidence of encroachment into the alluvial flood plain, SEZs by urbanization over time, and changes in channel morphology are identified.

4. Changes in landscape metrics and evidence of disturbance to ecosystem health indicators, such as the GIS data of forest mortality, old growth tree stands, and animal habitat are studied.

5. After the accuracy of the IKONOS classification is established through analysis and fieldwork, tables of classification successes and error matrices with LULC datasets will be derived from the HDOQs.

\section{Pilot Area}

High-resolution land cover mapping for the Lake Tahoe Basin includes current and historic land use mapping. Because the Tahoe Basin occupies a large area (506 square miles), a pilot area focused on the Upper Truckee River and Trout Creek watersheds near the city of South Lake Tahoe (fig. 2) has been chosen to test the methods and techniques proposed by this study. The pilot area was chosen because the two largest drainage systems, with correspondingly high sediment yields, flow through the area (McCarthy, 1997; Heyvaert, 1998). In addition, different landscape conditions and varying levels of imperviousness, which represent a range of water quality influences throughout the Basin, are represented here: from remote natural terrain to the most urbanized and impervious areas around the lake. In addition, the USGS has been involved with surface water studies in these watersheds since 1960, providing the longest record of streamflow and surface water quality data in the Basin (Rowe and Allander, 2000). 


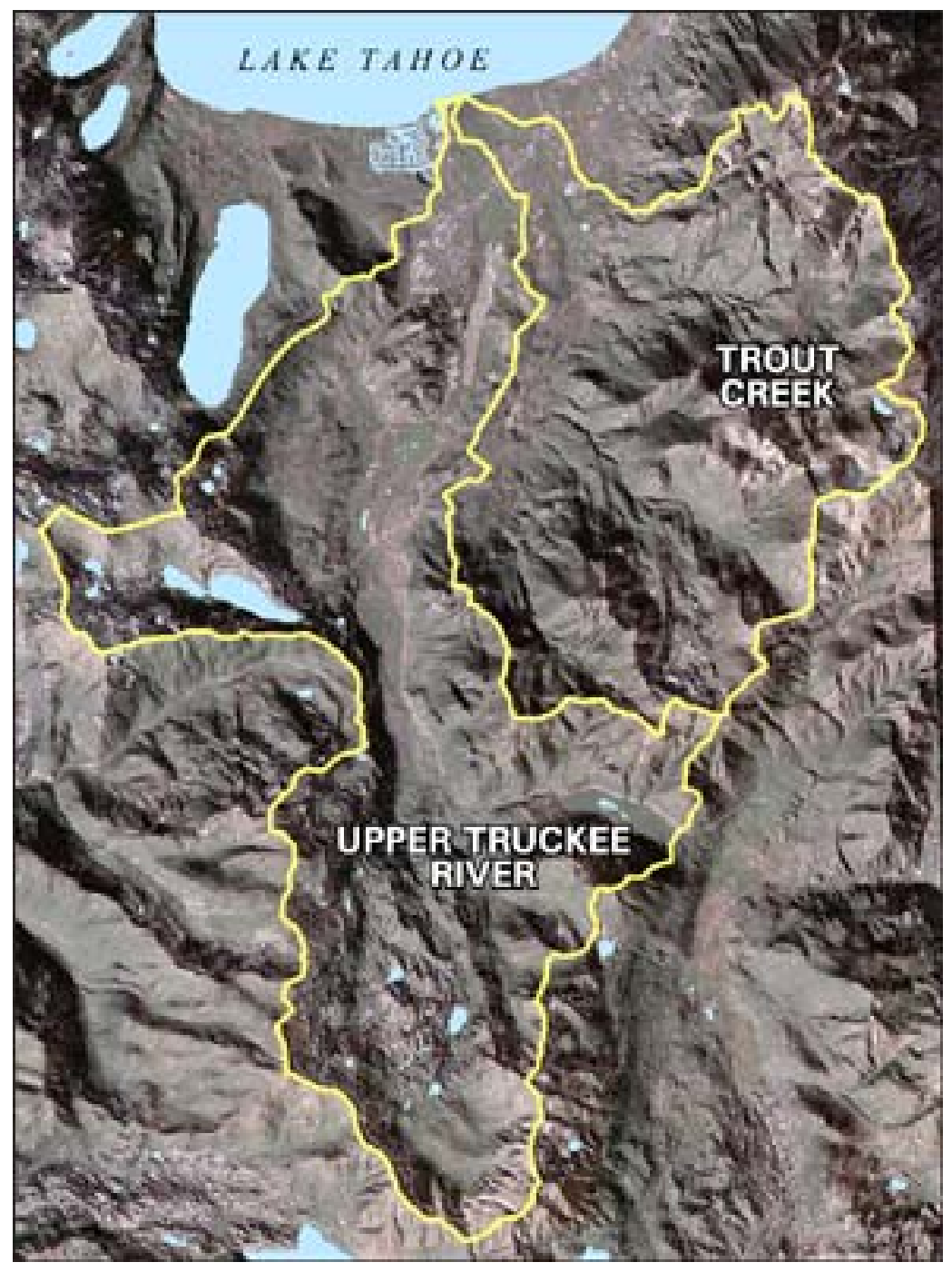

Figure 2. Map of the pilot study area consisting of the Upper Truckee River and Trout Creek watersheds in South Lake Tahoe.

The Upper Truckee River occupies 18 percent (56.5 square miles) of the land area tributary to Lake Tahoe and contributes the largest volume of surface water to the lake. The Upper Truckee also has the largest human population and urban development of any watershed in the Basin and may be a significant source of the increased nutrient and sediment loading to the lake. Trout Creek is immediately adjacent to the Upper Truckee River and together these two watersheds make up most of the South Lake Tahoe area. Historically, Trout Creek was at times a tributary to Upper Truckee River; however, development of the Tahoe Keys residential area resulted in the channelization of the river, separating it from the creek. Trout Creek is the second largest watershed in the Tahoe Basin and occupies 13 percent (41.2 square miles) of the total land area tributary to the lake (Rowe and Allander, 2000). Conceptually, the study area focuses on the Upper Truckee and Trout Creek catchments because those can be considered complete ecosystem units.

\section{Data Sources}

The mapping component of the project is being conducted using two primary data sources that have nested, yet different, spatial extents: HDOQs derived from aerial photography and high-resolution IKONOS multispectral imagery from Space Imaging Corporation (fig. 3). The HDOQs are being produced through an internal cooperative agreement between the research and data production sections at the USGS Western Geographic Science Center in 


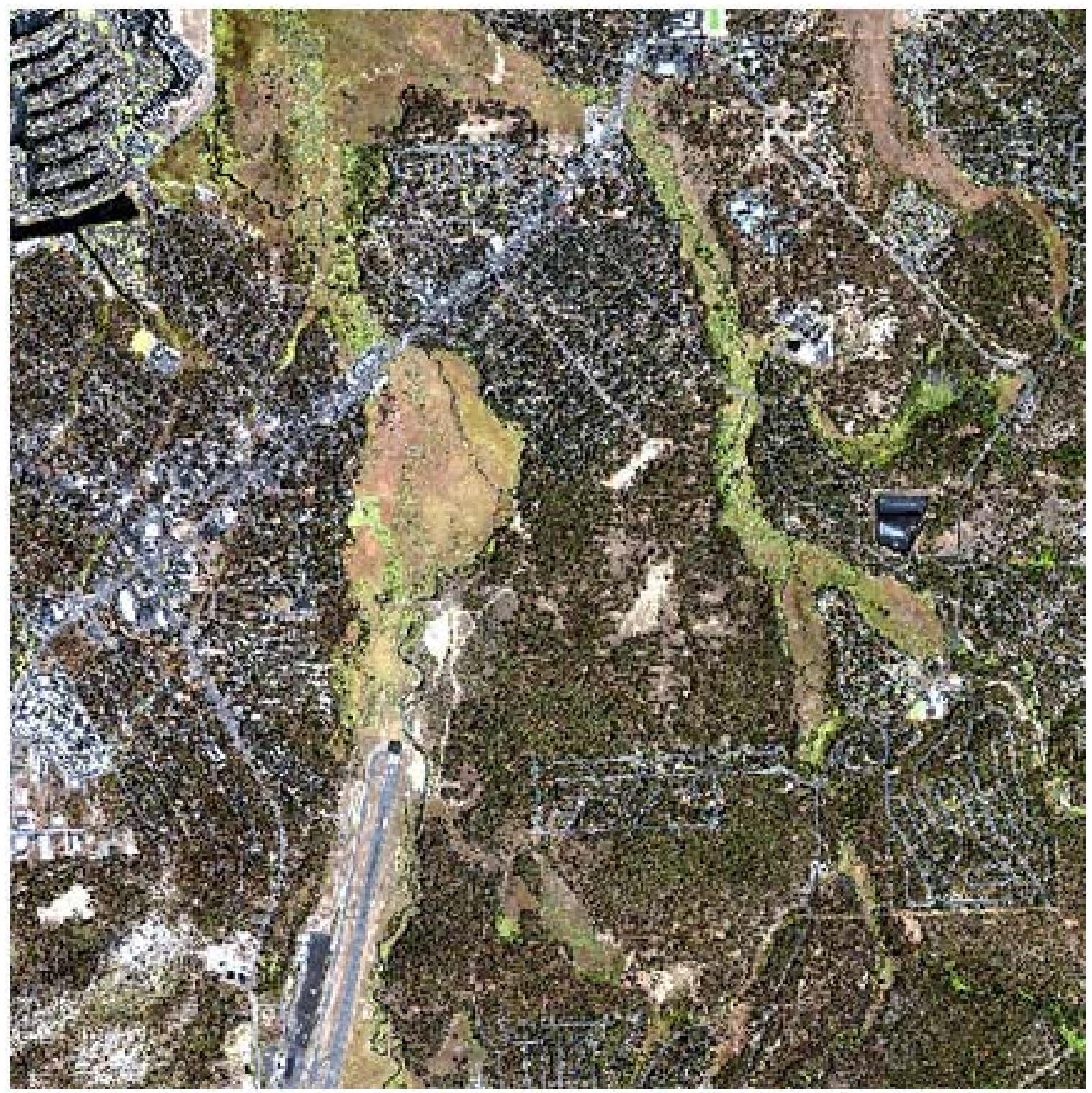

Figure 3. IKONOS scene covering a part of South Lake Tahoe. The image was acquired August 10, 2000, and covers an area of approximately 9.6 square miles (25 square kilometers). The false-color composite consists of 4meter resolution multispectral bands sharpened with the 1-meter resolution panchromatic band.

Menlo Park, Calif. The IKONOS imagery was purchased commercially under a multi-licensing agreement with partners at TRPA and DRI.

We will explore the usefulness of using high-resolution IKONOS satellite imagery for detailed impervious surfaces and natural land cover mapping. The project contributes to the development of new techniques for using IKONOS data for land use applications. A component of this work will be to investigate the tradeoffs between multispectral semiautomated classification techniques and traditional manual interpretation.

\section{Historical DOQs}

Aerial photography has historically been the primary source for deriving high-resolution land cover information, whereas satellite imagery, such as Landsat MSS or TM, has been used for applications not requiring a high degree of 
spatial resolution. There has traditionally been a tradeoff between higher spatial resolution (aerial photography) and higher spectral resolution (Landsat and similar satellite platforms). As satellite-imaging systems evolve to yield higher resolution multispectral sensors (such as IKONOS with a 1-meter resolution panchromatic band combined with a 4-meter resolution multispectral band), there will be less need for relying on aerial photographs. In today's computer analysis and GIS environments, aerial photographs are typically scanned and processed into orthophotographs and therefore require more manual processing than satellite-based imagery. Although orthophotos are an ideal photographic source for deriving vector information, the focus of this study in deriving land cover information may dictate raster-based data as being more useful.

A scarcity of land use and land cover data for the Tahoe Basin requires a significant and comprehensive data collection effort to commence this project. Historical aerial photographs have been obtained for the pilot area for the following time periods: 1940 (fig. 4), 1969, and 1987. DOQs at a 1-meter resolution currently exist for 1992 and 1998. The selected temporal resolution uses the best available photograph sources and captures the landscape approximately every decade, with an increased time step in the past 20 years when stream gage data were more consistently available. This temporal resolution will also provide enough data to document channel migration rates and other occurrences that have affected the SEZs. Phenomena such as stream incision or changes in gradient will be difficult to document, nevertheless, the measurement and quantification of changes within the pilot area SEZs over the last 60 years will be information otherwise unavailable.

Historical photographs will be orthorectified and processed by USGS DOQ production staff at the Western Geographic Science Center in Menlo Park. There are challenges and nuances associated with producing standard USGS products using nontraditional data sources; however, initial processing has shown that the process can be accomplished with a high degree of success. The promise of a program dedicated to a product to document landscape change over the past 60+ years is enormous. The popularity of the DOQs for the Tahoe Basin representing two temporal snapshots (1992 and 1998) has been tremendous. Researchers and regulatory in the Tahoe Basin have responded positively to the plan to offer HDOQs.

In addition to being the primary data to derive historical and current LULC classifications, the HDOQs produced for this project-as well as existing Tahoe Basin DOQs for 1992 and 1998-will serve as the primary source for developing the temporal transportation layer 4 The database describing the road network will identify roads as present during a given time period or not. It will also indicate if a road is paved or unpaved. Railroads will also be mapped but classified as separate features from regular roadways. Impervious cover coefficients will be associated with different road types to obtain accurate area estimations (see McGurk and Davis, 1996). This dataset will provide quantitative information on landscape structure and will assist in the interpretation of land cover classes.

\section{High-Resolution Multispectral Imagery}

Although DOQs are an excellent high-resolution data source, the time and energy required to manually process, interpret, and classify the data are immense. Therefore, we are testing IKONOS imagery as a possible substitute to traditional aerial photographs. Because IKONOS imagery consists of both 1-meter panchromatic data as well as 4meter multispectral data, we will assess if IKONOS is easier, more efficient, less expensive, and more informative than DOQs. Furthermore, because we have chosen a classification scheme that focuses on land cover, we will assess the ease, efficiency, and accuracy tradeoffs between manual classification of DOQs and digital classification of satellite imagery.

\footnotetext{
${ }^{3}$ The year 1982 is an additional consideration for the historical mapping as it would contribute to the understanding of change over the past 20 years. Due to the high costs of data purchase, 1982 will not be mapped as part of the year one pilot study.

${ }^{4}$ Road mapping activities will be conducted in a complementary way to current U.S. Forest Service mapping of system and nonsystem roads; data sharing is a mutual goal. In 1998, GPS and mapping work was completed by the U.S. Forest Service Lake Tahoe Basin Management Unit to update the USGS 1:24,000-scale digital line graph (DLG) files. This update includes GPS-defined locations of Forest Service roads and trails. The DLG is a Level 3 (DLG-3) enhanced product, which means it contains a full range of attribute codes, has full topological structuring, and has passed quality control checks.
} 


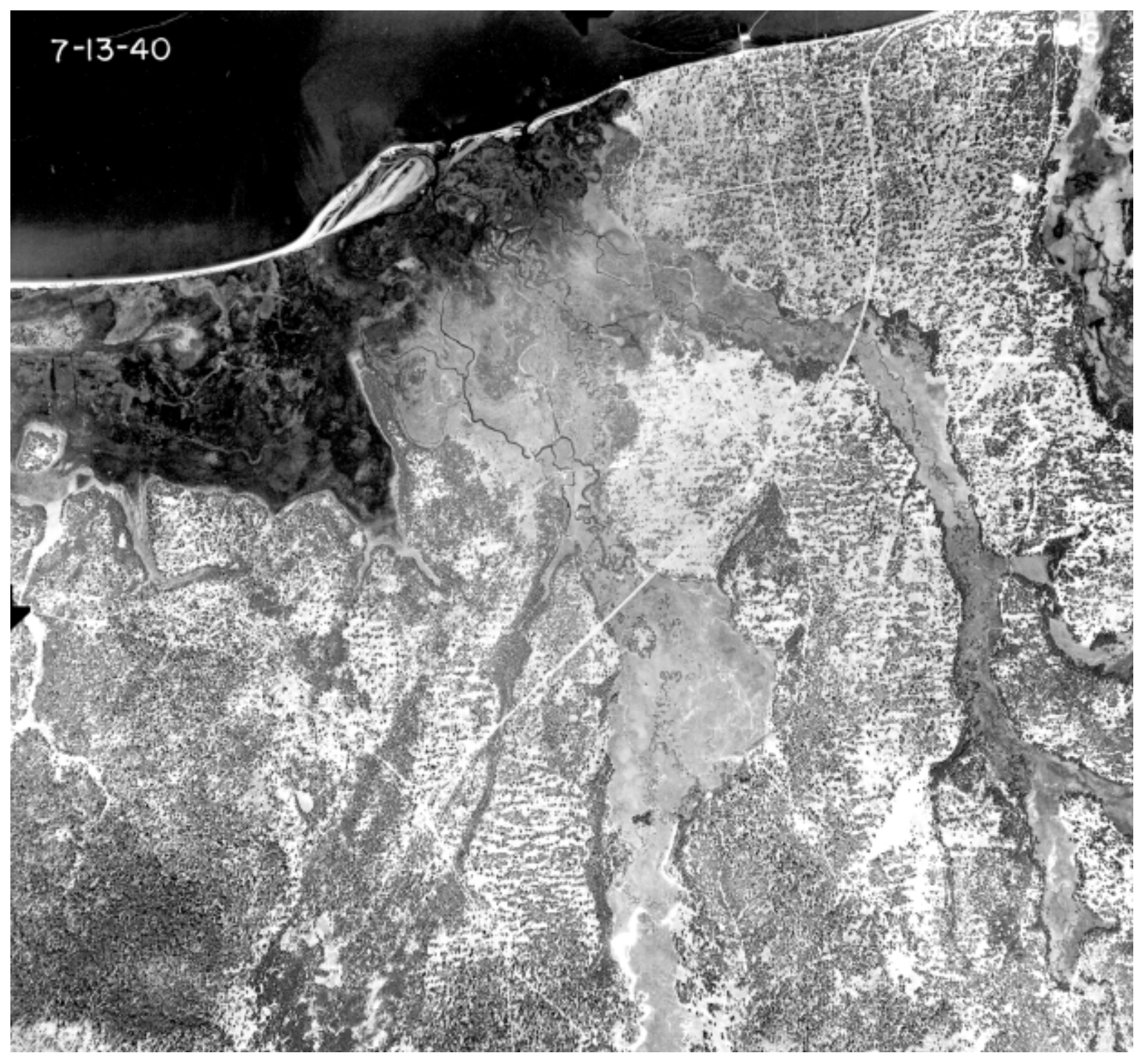

Figure 4. Aerial photograph showing a part of the South Lake Tahoe area in 1940. This view is before the construction of the Tahoe Keys in the Truckee Marsh complex and the other urbanization that we see today in western and southern South Lake Tahoe.

Because of the high purchase costs for the Space Imaging IKONOS data, a small scene was acquired for a 9.65square-miles (25-square-kilometer) area. The scene is centered on the South Lake Tahoe area and is substantial enough to represent a variety of land cover types in the area (and the Basin). Once IKONOS has successfully been used to conduct necessary project research, we will evaluate a data purchase for the entire pilot area and the rest of the land area in the Basin. Other high-resolution multispectral satellites (such as Earthwatch) will also be considered for integration into the project, especially if their purchase costs are lower for the same spatial resolution. Once the techniques for both the historical and contemporary mapping of the pilot area have been finalized, mapping will be expanded to include the approximately $800-\mathrm{km}^{2}$-land surface of the Basin.

Using ERDAS IMAGINE software, we will pay particular attention will be paid to the development of multispectral classification techniques for the following: 
- Discerning urban uses within the impervious cover classification system, such as commercial, residential, infrastructure, and industrial land use types.

- Locating regions that act as sources of nutrients and sediment, such as forest areas of prescribed burns and high tree mortality, road cuts on steep slopes, degraded stream channels, and other specific natural land cover types.

- Distinguish between natural land cover ecotones such as conifer, deciduous, alpine meadows, and riparian (FGDC, 1996).

The results of this work will help to answer the fifth hypothesis and compare the utility of the two (the IKONOS -based and the HDOQ-based) LULC classification system to other systems, such as the USGS National Land Cover Dataset (NLCD), Gap Analysis, the U.S. Department of Agriculture Watershed Assessment vegetation layer, and other Landsat- and SPOT-derived systems. The utility will orient on classifications that are indicative of relevant ecosystem processes. From previous studies, it appears that IKONOS can resolve impervious surfaces to a much greater accuracy than Landsat-based classification systems (Cablk and Minor, 2001). Furthermore, the utility of IKONOS imagery to discern natural cover types will be compared with that of HDOQs.

\section{Classification Considerations}

Various potential classification schemes were considered for the temporal LULC mapping component of this project. Some schemes categorized LULC on the basis of imperviousness (Prisloe and others, 2001; Botsford and others, 2000; Sleavin and others, 2000; Crnojacki and others, 1997; Civco and Hurd, 1997; Khorram and others, 1992) while others concerned themselves with a mixture of land use and land cover without an emphasis on imperviousness (Lorenz and Stoner, date unknown; USGS, November 1999; NOAA-CSC, 1995; Anderson and others, 1976).

The classification of urban data must be sensitive to the research and policy needs of others; therefore, we must go beyond the simple classification of urban versus nonurban. A more detailed classification of urban lands that distinguishes between residential, commercial, industrial, and other uses is essential for understanding how urban areas are growing and changing. Therefore, an integrated approach to assembling land cover and land use data is essential. Urban data that distinguishes between impervious and nonimpervious surfaces are critical in order to meet the needs of water quality researchers (Civco and Hurd, 1997; Berka and others, 1995). The correlation of impervious cover with associated land use is an important regulatory evaluation need of TRPA. If planners and other local land use decision-making agencies such as TRPA can combine their parcel information with actual land use data, they can have a better understanding of the carrying capacity of the land.

A hierarchical classification system will be used for land cover mapping, which allows the classification of major land use types (urban, forest, agriculture, rangeland, wetlands, water, and barren lands), as well as minor land use types (residential, commercial, industrial, and so on) and impervious surfaces (low-, medium-, and highintensity imperviousness) (Wilke and Finn, 1996; Lillesand and Kiefer, 1994; Chuvieco and Congalton, 1988; and Anderson and others, 1976). To maintain consistency with other land use and land cover mapping activities of the USGS National Mapping Program, we will draft and refine a hierarchical classification scheme that is a subset of the scheme developed for the USGS National Land Cover Dataset (NLCD) 2000 mapping effort. This approach allows the capture of high-resolution features from the aerial photographs in a system that can be aggregated and compared on a regional basis. A stratified cluster sampling strategy (Urban, 1999) will be applied through fieldwork with global positioning system (GPS) units. This efficient sampling scheme will be used to determine classification accuracy, and fix mixed-pixel problems.

\section{Analysis Techniques}

Landscape ecology, as a relatively new discipline, focuses on broad spatial scales and the ecological effects of the spatial patterning of ecosystems. Specifically, it considers (1) the development and dynamics of spatial heterogeneity, (2) the interactions and exchanges across heterogeneous landscapes, (3) the influences of spatial heterogeneity on biotic and abiotic processes, and (4) the management of spatial heterogeneity (Pielou, 1975). The focus of the discipline is on landscapes, which can be described by three primary components: structure, function, 
and change. $\tilde{Q}$ Quantitative methods are used to compare, contrast, and track changes in and between landscapes, and to relate these patterns to ecological function (Turner, 1989). This is the most difficult part; to go beyond simply describing a landscape to actually linking systems with appropriate metrics to determine statistical relationships that can inform the tensions between land use change, anthropogenic needs, and natural phenomena.

The ability to quantify landscape structure is a prerequisite to the study of landscape function and change (McGarigal, 2001). To quantify landscape structure, we will use spatial pattern analysis software known as FRAGSTATS*Arc. Landscape ecology emphasizes the study of landscape patterns, the interactions among patches within a landscape mosaic, and how these patterns and interactions change over time. FRAGSTATS*Arc provides metrics relating this information using spatial data such as that being developed for this study. FRAGSTATS*Arc metrics of interest include area calculations, patch density, size and variability, edge and shape quantifications, diversity values, and contagion and interspersion metrics.

An additional part of this analysis will be to provide a socioeconomic perspective of the motivators of urban growth. Population and related socioeconomic data for the basin will be collected from literature and other sources, including the U.S. Census and the California Department of Finance. This ancillary information will be gathered with respect to the geography and temporality of mapping activities.

\section{Analysis of Water Quality}

Long-term data on the streamflow nutrient concentrations and suspended sediment concentrations for streams entering the lake have been collected since 1978, and streamflow volume measurements have been collected since 1961. LTIMP, comprising a host of agencies, has developed a significant database of continuous streamflow, nutrient and suspended sediment concentrations, and water quality data for 10 sites in 10 basins 6 LTIMP has also collected instantaneous streamflow measurements with nutrient and suspended sediment concentrations, as well as water quality data for an additional 14 sites. LTIMP hydrologic and water quality data from water years 1980 to the present are also readily accessible in electronic format in USGS databases. This project will attempt to relate temporal changes in land use and spatial differences in various physical factors to changes in nutrient and suspended sediment concentrations, streamflow, temperature, and other water quality characteristics.

In an attempt to test the first hypothesis, we will construct a water balance to assess the function of the hydrologic cycle through time. Starting in 1961, the gage at the base of Heavenly Valley (table 1) possesses the longest streamflow record in the LTIMP database. This will be used to assess how the interactions between runoff, infiltration, evapotranspiration, and ground water have evolved through time.

In addition to creating a water balance, we will construct two hydrographs from similar climatic and storm events: one from the 1960s and one for the present. These hydrographs will then be related to changes in impervious coverage area above and adjacent to the gages in question. The theory regarding changes in hydrographs caused by increasing impervious coverage is well documented (Borchardt and Sperling, 1997; Chou and others, 1988; EPA, 1983), but empirically it has not been well tested in the Tahoe Basin. As the theory states, a hydrograph under urbanized conditions should have (a) a shorter time interval between the inception of and peak flow, (b) a greater volume of water at peak flow, and (c) a faster falling limb of the graph as the precipitation event ends. A comparison of the two hydrographs will provide a measure of impacts caused by land use change.

Part of the work in assessing the hydrologic impacts of land use change will be to incorporate the Soil Conservation Service (SCS) rainfall-runoff techniques to quantify increases in runoff associated with urbanization (Chou and others, 1988; McClintock and others, 1995; Bhaduri and others, 1997). This technique depends on the Curve Number $(\mathrm{CN})$ values associated with particular hydrologic soil groups, which can be calculated from the NRCS soils coverage (table 3$)$. In a GIS, excess rainfall $\left(P_{e}\right)$ can be calculated using the equation:

$$
P_{e}=(P-0.2 S)^{2} /(P+0.8 S)
$$

\footnotetext{
${ }^{5}$ Structure is the spatial relationships between distinctive ecosystems and the distribution of energy, materials, and species with the different sizes, shapes, numbers, kinds, and configurations of the component parts. Function is the interactions between the spatial elements, that is the flow and exchange of energy, materials, and organisms among the component parts. Change is the alteration in the structure and function of the ecological mosaic through time. ${ }^{6} 5$ of the 10 watersheds-Incline, Trout, Edgewood, and Ward Creeks, and the Upper Truckee River-have multiple gages along their reaches, allowing for subwatershed analyses.
} 
Table 1. Periods of record for daily streamflow, water-quality, and suspended sediment data at current and historic USGS gaging stations and sampling sites for Upper Truckee River and Trout Creek watersheds. Adapted from Rowe and Allander (2000). (Water quality: NUT indicates instantaneous nutrient samples; SC indicates daily specific conductance; WT indicates daily water temperature. Suspended sediment: DAILY indicates daily suspended sediment; INST indicates instantaneous suspended sediment discharge [abbreviations from U.S. Forest Service].)

\begin{tabular}{|c|c|c|c|c|c|}
\hline $\begin{array}{l}\text { Site } \\
\text { No. }\end{array}$ & Site Name & Station No. & $\begin{array}{c}\text { Daily } \\
\text { Streamflow }\end{array}$ & Water Quality & Suspended Sediment \\
\hline 6 & $\begin{array}{l}\text { Upper Truckee } \\
\text { River at Hwy 50, } \\
\text { South Lake } \\
\text { Tahoe (gage) }\end{array}$ & 10336610 & $\begin{array}{l}\text { 1972-74, } 77, \\
78,80 \text {-current }\end{array}$ & $\begin{array}{l}\text { WT: 1972-74, } \\
78,80-92 \\
\text { SC:1981-83 } \\
\text { NUT: 1993- } \\
\text { current }\end{array}$ & $\begin{array}{l}\text { DAILY: } 1972-74,78 \text {, } \\
80-92 \\
\text { INST: } 1993 \text {-current }\end{array}$ \\
\hline 17 & $\begin{array}{l}\text { Upper Truckee } \\
\text { River at Hwy } 50 \\
\text { above Meyers } \\
\text { (gage) }\end{array}$ & 103366092 & 1990-current & $\begin{array}{l}\text { NUT:1990- } \\
\text { current }\end{array}$ & INST: 1990-current \\
\hline 20 & $\begin{array}{l}\text { Upper Truckee } \\
\text { River near } \\
\text { Meyers (inactive } \\
\text { gage) }\end{array}$ & 10336600 & 1961-1986 & & \\
\hline 43 & $\begin{array}{l}\text { Upper Truckee } \\
\text { River at S. Upper } \\
\text { Truckee Road } \\
\text { (gage) }\end{array}$ & 10336580 & 1990-current & $\begin{array}{l}\text { NUT: 1990- } \\
\text { current }\end{array}$ & INST: 1990-current \\
\hline 49 & $\begin{array}{l}\text { Trout Creek at } \\
\text { Hwy 50, South } \\
\text { Lake Tahoe }\end{array}$ & 10336790 & & $\begin{array}{l}\text { WT: 1972-74, } \\
89-92 \\
\text { NUT: 1993- } \\
\text { current }\end{array}$ & $\begin{array}{l}\text { DAILY: 1972-74, 89- } \\
92 \\
\text { INST: 1993-current }\end{array}$ \\
\hline 52 & $\begin{array}{l}\text { Trout Creek at } \\
\text { Martin Ave near } \\
\text { Tahoe Valley } \\
\text { (gage) }\end{array}$ & 10336780 & 1961-current & $\begin{array}{l}\text { WT: } 1972-74 \text {, } \\
78,80-85,88 \\
\text { SC: } 1981-83\end{array}$ & $\begin{array}{l}\text { DAILY: } 1972-74,78 \text {, } \\
\text { 80-85, } 88 \\
\text { INST: } 1990 \text {-current }\end{array}$ \\
\hline 57 & $\begin{array}{l}\text { Trout Creek at } \\
\text { Pioneer Trail } \\
\text { near South Lake } \\
\text { Tahoe (gage) }\end{array}$ & 10336775 & 1990-current & $\begin{array}{l}\text { NUT: 1990- } \\
\text { current }\end{array}$ & INST: 1990-current \\
\hline 68 & $\begin{array}{l}\text { Trout Creek at } \\
\text { U.S. Forest } \\
\text { Service Road } \\
\text { 12N01 near } \\
\text { Meyers (gage) }\end{array}$ & 10336770 & 1990-current & $\begin{array}{l}\text { NUT: 1990- } \\
\text { current }\end{array}$ & INST: 1990-current \\
\hline
\end{tabular}

Where $P$ equals precipitation and $S$ equals some potential maximum retention by soils. The precipitation can be obtained from the PRISM data (PRISM precipitation maps, 2001) or SNOWTEL gages. Forest and meadow infiltration rates for some soils in the Tahoe Basin have been estimated (Burcar and others, 1994). For values of $S$ that could not be obtained from the literature, they can be estimated with the help of the following equation:

$$
S=1000 / \mathrm{CN}-10
$$


Then, using the appropriate $\mathrm{CN}$ values, we could compare the natural cover-type calculation of excess rainfall with the excess rainfall from urbanization (Forney, 1999).

Mass balance equations have been used to derive concentration-discharge relations under conditions of varying concentration, inflow, discharge, volume, and dissolved load. Studies in the Tahoe Basin, particularly Upper Truckee River and Trout Creek, have indicated that models can be used to distinguish anthropogenic nitrate sources from the ionic pulse associated with early snowmelt (Coats, 1992). These models, however, are sensitive to variations in discharge: in base flow years with normal spring-melt runoff conditions, discharge is more consistent, therefore linear regressions can explain more of the variation. In nonbase flow years, linear relationships are less likely to apply and alternative methods will need to be considered. The spatially explicit, export coefficient methodology presented by Mattikalli and Richards (1996) offers suggestions on how to improve upon mass balance equations to estimate surface water quality changes in response to land use changes.

Furthermore, these regression models do not account for the influence of spatial pattern upon the flow of matter and nutrient through a landscape and the interactions of the stream courses with the upland land surface (Turner, 1989). In an attempt to test the second hypothesis, we will investigate the utility of the landscape metrics to find statistically significant relationships between land use change and alterations in parameters of water quality. Class and landscape metrics of interest are percentage of cover type, area, number of patches, mean patch size, and patch richness. Water quality parameters of interest are stream discharge, suspended sediment, water temperature, and bioavailable nitrogen, phosphorous, and iron.

\section{Analysis of Ecosystem Health}

There is little quantitative information concerning historical changes to the SEZs in the South Lake Tahoe area. Aerial photography is one of the only available sources for assessing the changes that have affected SEZs. As we understand changes to SEZs, we better equip ourselves with the knowledge of how human activities are affecting watersheds within the Tahoe Basin and the region as a whole (Weller and others, 1997).

Preliminary comparisons between the georectified photographs and existing DOQs of the South Lake Tahoe area indicate that changes to SEZs have occurred over the last 60 years. These changes include channel migrations and avulsions, changes to the structure and composition of riparian vegetation, channelization projects, impoundments, and development within the SEZs. Each of these changes has implications for the water quality of the fluvial systems and for the quantity of sediment and nutrients delivered to Lake Tahoe from these systems. Once HDOQs are prepared for additional analysis, changes in the SEZs along the Upper Truckee River and Trout Creek will be quantified with such metrics as channel length, area, density, and sinuosity (Binford and Buchenau, 1993). These metrics will then be correlated with water quality data prepared by Kilroy and others (1997) and the LTIMP gages listed in Table 1 to test whether a significant relationship between SEZ changes and water quality changes exists. Given the aerial extent of historical riparian zones, area of disturbance and percentage of change metrics will be compiled to test the third hypothesis of this project.

One of the necessary components of this analysis is to derive metrics that can be compared across time and the two resolutions of data sources. Because of their correlation, 55 landscape metrics can been narrowed down to 6 (Riitters and others, 1995): dominance, contagion, fractal dimension from perimeter/area, average patch perimeter/area ratio, average patch/perimeter/area orthogonally adjusted, and number of classes. Of those, the EPA maintains that changes in landscape patterns are best characterized by three metrics: contagion, fractal dimension, and dominance (EPA, 1994). Their application, however, may not be similar to ours, and those metrics may miss water quality metrics and ecosystem health indicators. In 1998, Frohn found that contagion and fractal dimension were not appropriate metrics owing to problems with perimeter/area relationships, regression estimates, consistency, diversity, and spatial resolution, and he suggested two alternative ones: Patch-Per-Unit (PPU) area and Square-Pixel (SqP). He compared the four metrics in five experiments dealing with spatial resolution, spatial gradients, vertical gradients, and temporal gradients. For four of these experiments, he used study sites in the Sierra Nevada, Washington, DC, Rondonia, Brazil, and Ouro Preto, Brazil. The metrics discussed here will help elucidate some of the changes in structure over time (Dunn and others, 1990), and metrics such as contagion, PPU area and dominance have direct relevance to ecosystem health as they are a measure of integrity, structure, and function.

It has been suggested that human-influenced systems exhibit simpler patterns than natural landscapes. For example, smaller patch size and simpler fractal dimension have been proved to indicate a fragmented structural 
pattern between old growth landscapes of eastern hemlock (Tsuga canadensis), sugar maple (Acer saccharum), and yellow birch (Betula allegheniensis) (Mladenoff and others, 1993). The assertions of Mladenoff and others (1993) are in direct contradiction with Frohn (1998), as well as statements made elsewhere in the literature (Krummel and others, 1987, O'Neill and others, 1988, Turner and Ruscher, 1988). With the consistent classification systems and datasets that will be produced from the HDOQs, the ability to measure landscape disturbance will be tested by a metric of fractal dimension, as well as its measure of complexity over time.

Furthermore, metrics such as density of urban lands, urbanized acreage, and total miles of roads (paved versus unpaved) will be compiled. FRAGSTATS*Arc software will be used to derive metrics related to the basin-wide landscape, land cover types within landscapes, as well as specific patches of cover type within a landscape (Nautilus, 12/12/2000). In addition, other metrics suggested previously will be used to test the fourth hypothesis; this testing will reveal the ability of these metrics to characterize landscape pattern and change over time and will show how that characterization relates to changes in natural and anthropogenic cover types.

Given the historical and current structural integrity of the landscape, key indicator species can be used to assess the function of an ecosystem. Biologically significant species that have been recognized as sensitive, threatened, endangered and/or used as a management indicator species are listed in table 2 (Bish and Kundert, unpublished report for TRPA).

Table 2. Biologically significant species found in the Lake Tahoe Basin. Compiled for purposes of habitat management and metapopulation dynamics.

\begin{tabular}{|c|c|c|c|}
\hline Plants & Amphibians & Mammals & Birds \\
\hline $\begin{array}{l}\text { Galena Creek rockcress } \\
\text { (Arabis rigidissima) }\end{array}$ & $\begin{array}{l}\text { Mount Lyell salamander } \\
\text { (Hydromantes } \\
\text { platycephalus) }\end{array}$ & $\begin{array}{l}\text { Black bear (Ursus } \\
\text { americanus) }\end{array}$ & $\begin{array}{l}\text { American peregrine } \\
\text { falcon (Falco peregrinus } \\
\text { anatum) }\end{array}$ \\
\hline $\begin{array}{l}\text { Long-petaled lewisia } \\
\text { (Lewisia longipetala) }\end{array}$ & $\begin{array}{l}\text { Mountain yellow-legged } \\
\text { frog (Rana muscosa) }\end{array}$ & $\begin{array}{l}\text { American marten } \\
\text { (Martes americana) }\end{array}$ & $\begin{array}{l}\text { Bald eagle (Haliaeetus } \\
\text { leucocephalus) }\end{array}$ \\
\hline $\begin{array}{l}\text { Soda Springs silene } \\
\text { (Silene invisa) }\end{array}$ & & $\begin{array}{l}\text { Mule deer (Odocoileus } \\
\text { hemionus) }\end{array}$ & $\begin{array}{l}\text { Blue grouse } \\
\text { (Dendragapus obscurus) }\end{array}$ \\
\hline $\begin{array}{l}\text { Star draba (Draba } \\
\text { asterophora) }\end{array}$ & & $\begin{array}{l}\text { Sierra Nevada red fox } \\
\text { (Vulpes vulpes necator) }\end{array}$ & $\begin{array}{l}\text { California spotted owl } \\
\text { (Strix occidentalis } \\
\text { occidentalis) }\end{array}$ \\
\hline $\begin{array}{l}\text { Tahoe draba (Draba } \\
\text { asterophora } \\
\text { 'Macrocarpa') }\end{array}$ & & Fisher (Martes pennanti) & $\begin{array}{l}\text { Golden eagle (Aquila } \\
\text { chrysaetos) }\end{array}$ \\
\hline \multirow[t]{4}{*}{$\begin{array}{l}\text { Tahoe yellow-cress } \\
\text { (Rorippa subumbellata) }\end{array}$} & & & $\begin{array}{l}\text { Northern goshawk } \\
\text { (Accipiter gentiles) }\end{array}$ \\
\hline & & & $\begin{array}{l}\text { Osprey (Pandion } \\
\text { haliaetus) }\end{array}$ \\
\hline & & & $\begin{array}{l}\text { Pileated woodpecker } \\
\text { (Dryocopus pileatus) }\end{array}$ \\
\hline & & & $\begin{array}{l}\text { Willow flycatcher } \\
\text { (Empidonax traillii) }\end{array}$ \\
\hline
\end{tabular}

The plants and animals of concern are each associated with particular habitats. Given the extent and quality of remote sensing imagery, the plants can be mapped and their disturbance documented over time. Remote sensing 
imagery cannot identify the occurrence of animals, but each animal has a preferred habitat that can be identified and assessed (National Gap Analysis Program). Furthermore, the Watershed Assessment gathered goshawk and California spotted owl sightings in the Basin that can complement and field-verify the determinations of preferred habitat.

With an improved understanding of local faunal behavior, the structure of the landscape pattern (both historical and current) can be assessed to determine its historical, present, and future ability to support viable populations and consider metapopulation dynamics (Urban and Smith, 1989; Stacey and Taper, 1992; McGarigal and Marks, 1994; and Keitt and others, 1997). Furthermore, the citing locations could be used linear regression techniques to create a basin-wide probability map of the likelihood of finding those species in a given location (Bernknopf and others, 2001). This could then be compared with historical, current, or planned areas of urban development and used to further test the fourth hypothesis.

As part of the assessment of ecosystem health, patterns of human development and environmental disturbance over time will be compared with existing GIS coverages from the recent past (Table 3). These coverages will aid in the presentation and synthesis of disparate information. Furthermore, the data will be investigated for their potential utility to inform the assessment of ecosystem health. Some initial suggestions for using these data follow.

Table 3. Potentially relevant GIS data for ecosystem health assessment; from Whitley, 2001; USGS, 2001; Ca Gap, 2001; California Tahoe Conservancy, 2001; Murphy and Knopp, 2000; and Cartier and others, 1993.

\begin{tabular}{lll}
\hline \multicolumn{1}{c}{ GIS Data } & Format & \multicolumn{1}{c}{ Resolution/Scale } \\
\hline Digital elevation models & Raster & 10 meter \\
Land cover (NLCD) & Vector & 30 meters \\
Land cover/land use, vegetation (CA Gap) & Vector & MMU=100 ha upland, 40 ha \\
Vegetation (Watershed Assessment) & Vector & 30 meters \\
Streams & Line & $1: 24,000$ \\
NRCS soils ${ }^{+}$ & Vector & $1: 24,000$ \\
Stream Environment Zones (2001) & Vector & \\
Riparian assessment from videography & Vector & 1 meter \\
Soil erosion hazard/fire risk & Raster & 30 meters \\
Old growth forests/fire risk & Raster & 30 meters \\
Urban areas/fire risk & Raster & 30 meters \\
Fuel model & Raster & 30 meters \\
Natural fire ignitions & Point & \\
Human fire ignitions & Point & \\
& Vector & \\
Goshawk sightings & Point & \\
California spotted owl sightings & Point & \\
Stream crossings and culvert locations & Vector & \\
Ecological unit inventory & Point \\
Forest mortality over time & & \\
Sierra Nevada old growth & Raster/Vec \\
Bailey Land Capability System & Raster/Vec & \\
\hline
\end{tabular}

+ The NRCS has updated its soil survey with a focus on beach and alluvial soils.

To understand an ecosystem, we must understand the risks, impacts and likelihood of historic and current disturbance regimes (Landres and others, 1999). Given the encroachment of human structures and build out zones, 
the data could be compared with the soil erosion and fire hazard risk map produced for the Lake Tahoe Watershed Assessment. (for documentation, see Chap. 5 of the Watershed Assessment). Also, the fuel-loading model, along with GPS locations of historical lightning strikes and human-triggered ignitions, can be used to create a likelihood of occurrence. Furthermore, the ignition points can provide information about the relation of the historical firedisturbance regime to the system and can be used to assess the increased disturbance from anthropogenic sources. Finally, given a model of fire behavior and linear regression techniques, a probability map of fire occurrence can be calculated (Bernknopf, unpublished report, 2001). Natural and human disturbances need to be understood to provide a comprehensive picture of the stage upon which natural resource management is acted out.

\section{STUDY RESULTS}

The USGS maintains a Website resource for the Basin known as the Lake Tahoe Data Clearinghouse (http://tahoe.usgs.gov). This established Website will serve as the primary mechanism for the release of data and results to the public and Tahoe researchers. In addition, journal articles and Open-File Reports will be published to engage the scientific community.

\section{ACKNOWLEDGMENTS}

We would like to acknowledge the following individuals that have been and will be integral in the activities and success of this project. Very special thanks to German Whitley, GIS Specialist with the USDA Forest Service Lake Tahoe Basin Management Unit for her incredible assistance with GIS data and project support. We are grateful also to our research peers at USGS Western Geographic Science Center in Menlo Park, Calif. Leila Gass, Alexander Evans, and John Vogel, have all made important contributions to the theory and techniques described in this report. Their collective assistance has been immensely helpful. We would also like to thank Sandi Page and Sonya Baird for their help with accounting arrangements and cooperative agreements.

\section{REFERENCES CITED}

Acevedo, W., Foresman, T.W., and Buchanan, J.T., 1996, Origins and philosophy of building a temporal database to examine human transformation processes, in ASPRS/ACSM Annual Convention and Exhibition, Baltimore, MD, April 22-24, 1996, [Proceedings] v. 1, p. 148-161.

Acevedo, W., Richards, L.R., and Buchanan, J.T., 1999, Analysis of land use change in urban environments: U.S. Geological Survey Fact Sheet FS 188-99, 4 p.

Adams, K.D., and Minor, T.B., 2001, Historic shoreline change at Lake Tahoe from 1938 to 1998: implications for water clarity: Reno, NV, Desert Research Institute, Report to the Tahoe Regional Planning Agency.

Anderson, J.R., Hardy, E.E., Roach, J.T., and Witmer, R.E., 1976, A land use and land cover classification system for use with remote sensor data: U.S. Geological Survey Professional Paper 964, 28 p.

Arnold, C.L., Jr. and Gibbons, C.J., 1996, Impervious surface coverage: the emergence of a key environmental indicator: Journal of the American Planning Association, v. 62, no. 2, p. 243-258.

Bank of America, 1996, Beyond sprawl: new patterns of growth to fit the new California, http://www.bofa.com/community/comm_env_urban1.htm (Mar. 4, 1999).

Bell, C., Acevedo, W., and Buchanan, J.T., 1995, Dynamic mapping of urban regions: growth of the San Francisco Sacramento region, in Urban and Regional Information Systems Association; San Antonio, TX, July 16-20, 1996 [Proceedings] v. 1, p. 723734. 
Berka, C., McCallum, D., and Wernick, B., 1995, Land use impacts on water quality: case studies in three watersheds, Presented at The Lower Fraser Basin in Transition: A Symposium and Workshop, May 4, 1995, http://www.ire.ubc.ca/ecoresearch/publica3.htm (Jan. 12, 2001).

Bernknopf, R.L., and Forney, W.M., 2000, Progress report for the assessment of the Tahoe Regional Planning Agency's land use system, unpublished report: U.S. Geological Survey, Center for Science Policy, Menlo Park, California.

Bhaduri, B., Grove, M., Lowry, C., and Harbor, J., 1997, Assessing long-term hydrologic effects of land use change: Journal of the American Water Works Association, v. 89, no. 11, p. 94-106.

Binford, M.W. and Buchenau, M.J., 1993, Riparian greenways and water resources, in Ecology of Greenways, Smitt, D.S. and Hellmund, P.C., eds.: p. 69-103.

Borchardt, D. and Sperling, F., 1997, Urban stormwater discharges: ecological effects on receiving waters and consequences for technical measures: Water Science and Technology, v. 36, no. 8-9, p. 173-178,

Botsford, E., Booth, D., and Hill, K., 2000, A rapid landcover classification method for use in urban watershed analysis: University of Washington. http://www.students.washington.edu/ebots/prism/landsat.htm

Boughton, C.J., Rowe, T.G., Allander, K.K., and Robledo, A.R., 1997, Stream and ground water monitoring program, Lake Tahoe Basin, Nevada and California: U.S. Geological Survey Fact Sheet FS-100-97, 6 p.

Bradbury, J.P., and Van Metre, P.C., 1997, A land-use and water-quality history of White Rock Lake reservoir, Dallas, Texas, based on paleolimnological analyses: Journal of Paleolimnology, v. 17, p. 227-237.

Brakebill, J.W., 2001, Analyzing effects of land use on ground-water quality in the Potomac River Basin. http://wwwdmdtws.er.usgs.gov/publications/abstract/maha1095_jwb.htm

Brun, S.E., and Band, L.E., 1999, Simulating runoff behaviour in an urbanizing watershed: University of North Carolina Department of Geography. http://www.unc.edu/depts/geog/them/models/hspf/hspfmodel.htm

Burcar, S., Miller, W.W., Tyler, S.W., and Johnson, D.W., 1994, Seasonal preferential flow in two Sierra Nevada soils under forested and meadow cover: Journal of the Soil Science Society of America, v. 58, p. 1555-1561.

Byron, E.R., and Goldman, C.R., 1987, Relationships of stream water quality to land use characteristics in the Tahoe Basin: A technical summary of changing water quality in Lake Tahoe: The first five years of the Lake Tahoe Interagency Monitoring Program: Tahoe Research Group, University of California at Davis, p. 1 -19.

Byron, E.R., and Goldman, C.R., 1989, Land-use and water quality in tributary streams of Lake Tahoe, California-Nevada: Journal of Environmental Quality, v. 18, p. 84-88.

Cablk, M., and Minor, T.B., 2001, Analyses of impervious cover in the Lake Tahoe Basin using remote sensing and geographic information systems: International Journal of Remote Sensing, in press.

California Department of Finance (CDOF), 1999, California county and city profiles. http://www.dof.ca.gov

California Department of Water Resources (CDWR), 1991, Truckee River Atlas: Sacramento, DWR Reprographics. 
California Gap Analysis Program (Ca GAP), 2001. http://www.biogeog.ucsb.edu/projects/gap

California Tahoe Conservancy, 2001, Riparian assessment from videography. http://www.tahoecons.ca.gov/library/rip data/

Cartier, K.D., Peltz, L.A., Smith, J.L, 1993, Development and documentation of spatial databases for the Lake Tahoe Basin, California and Nevada: USGS Water Resources Investigations Report 93-4182, 65 p.

Chou, V.T., Maidment, D.R., and Mays, L.W., 1988, Applied hydrology, McGraw-Hill, Inc.

Chuvieco, E., and Congalton, R.G., 1988, Using cluster analysis to improve the selection of training statistics in classifying remotely sensed data: Photogrammetric Engineering and Remote Sensing, v. 54, no. 9, p. 1275-1281.

Civco, D. L., and Hurd, J.D., 1997, Impervious surface mapping for the state of Connecticut, in ASPRS/ACSM Annual Convention and Exhibition, Seattle, Wash., [Proceedings] v. 3, p. 124-135.

Clark, S., Starr, J., Foresman, T.W., Prince, W., and Acevedo, W., 1996, Development of the temporal transportation database for the analysis of urban development in the Baltimore-Washington Region, in ASPRS/ACSM Annual Convention and Exhibition, Baltimore, Maryland, April 22-24 [Proceedings] v. 3, p. 77-88.

Clarke, K.C., and Gaydos, L.J., 1998, Loose-coupling a cellular automaton model and GIS: long-term urban growth prediction for San Francisco and Washington/Baltimore: International Journal of Geographical Information Science, v. 12, no. 7, p. 699-714.

Clarke, K.C., Gaydos, L.J., and Hoppen, S., 1997, A self-modifying cellular automaton model of historical urbanization in the San Francisco Bay area: Environment and Planning B, v. 24, p. 247-261.

Coats, R.N. and Goldman, C., 1993, Nitrate transport in subalpine streams, Lake Tahoe Basin, California-Nevada, USA: Applied Geochemistry, supplemental issue no. 2, p. 17-21.

Coats, R.N., Leonard, R.L., Goldman, C.R., 1976, Nitrogen uptake and release in a forested watershed, Lake Tahoe Basin, California: Ecology, v. 57, p. 995-1004.

Crawford-Tilley, J.S., Acevedo, W., Foresman, T.W., and Prince, W., 1996, Developing a temporal database of urban development for the Baltimore/Washington Region, in ASPRS/ACSM Annual Convention and Exhibition, Baltimore, Maryland, April 22-24 [Proceedings], v. 3, p. 101-110.

Crnojacki, Z., Law, N.L., Sorensen, E., Szwagiel, S., and Tenenbaum, D., 1997, Hydrologic land cover classification for the Northeast Humber Watershed. http://pingo.geog.toronto.edu/ davidten/wisqgih2/

Duane, T.P., 1996, Human settlement, 1850-2040, in Status of the Sierra Nevada: the Sierra Nevada Ecosystem Project final report to Congress, D.C. Erman, ed.: Davis, CA, Centers for Water and Wildlands Research, v. 2, p. 235-360.

Dunn, C.P., Sharpe, D.M., Guntenspergen, G.R., Streans, F., and Yang, Z., 1990, Methods for analyzing temporal changes in landscape pattern, in Quantitative Methods in Landscape Ecology, M.G. Turner and R.H. Gardner, eds. Springer-Verlag, p. 173198.

Elliot-Fisk, D.L., Cahill, T.C., Davis, O.K., Duan, L., Goldman, C.R., Grunell, G.E., Harris, R., Kattleman, R., Lacey, R., Leisz, D., Lindstrom, S., Machida, D., Rowntree, R., Rucks, P., Sharley, D.A., Stephens, S.L., and Ziegler, D.S., 1996, Lake Tahoe Case 
Study. Status of the Sierra Nevada: the Sierra Nevada Ecosystem Project final report to Congress: D.C. Erman, ed.: Davis, CA, Centers for Water and Wildlands Research, addendum, p. 217-276.

Environmental Protection Agency (EPA), 1994, Landscape monitoring and assessment research plan, EPA 620/R-94/009, Washington, DC, Office of Research and Development.

Environmental Protection Agency (EPA), 1983, Results of a nationwide urban runoff program: Washington, DC, PB 84-185552, US EPA, Water Planning Division.

Federal Geographic Data Committee (FGDC), 1996, FGDC vegetation classification and information standards: FGDC Secretariat, Reston, VA.

Forney, W.M., 1999, The volumetric runoff and erosion model: a landscape perspective of erosion and land use in the Upper Truckee watershed, Lake Tahoe, California: Durham, NC, Duke University, Master's project, 42 p.

Frohn, R.C., 1998, Remote sensing for landscape ecology: new metric indicators for monitoring, modeling, and assessment of ecosystems: Boca Raton, FL, Lewis Publishers.

Goldman, C.R., 1988, Long-term limnological research at Lake Tahoe, in International Watershed Symposium [Proceedings]: South Lake Tahoe, CA, Tahoe Resource Conservation District, p. 464-477.

Goldstein, M.A., 1988, Truckee's Chinese community: from coexistence to disintegration, 1870-1890: Los Angeles, University of California, Master's thesis.

Hatch, L.K., 1997, The generation, transport, and fate of phosphorus in the Lake Tahoe Ecosystem: Dissertation in the Department of Ecology, UC Davis, CA.

Heyvaert, A.C., 1998, The biogeochemistry and paleolimnology of sediments from Lake Tahoe, California-Nevada: Dissertation, UC Davis, CA.

Hinkle, G.H., and Hinkle, B.M., 1997, Sierra Nevada Lakes: Reno, NV, University of Nevada Press, reprint of 1949 edition.

Howard, T.F., 1998, Sierra crossings: first roads to California: Berkeley and Los Angeles, CA, University of California Press, 226 p.

Irons, C.D., ed., 1885, W.F. Edwards' Tourist guide and Directory of the Truckee Basin: Truckee, CA, Republican Job Print.

Keitt, T.H., Urban, D.L., and Milne, B.T., 1997, Detecting critical scales in fragmented landscapes: Conservation Ecology, v. 1(1):4. http://www.consecol.org/vol1/iss1/art4

Kilroy, K.C., Lawrence, S.J., Lico, M.S., Bevans, H.E., and Watkins, S.A., 1997, Water-quality assessment of the Las Vegas Valley area and the Carson and Truckee River basins, Nevada and California: nutrients, pesticides, and suspended sediment, October 1969 to April 1990: U.S. Geological Survey Water Resources Investigations Report 97-4106, 144 p.

Kirtland, D., Gaydos, L.J., Clarke, K.C., De Cola, L., Acevedo, W., and Bell, C., 1994, An analysis of human-induced land transformations in the San Francisco Bay/Sacramento area: World Resource Review, v. 6, no. 2, p. 206-217.

Khorram, S., Cheshire, H., Siderelis, K., and Nagy, Z., 1992, Mapping and GIS development of land use and land cover categories for the Albemarle-Pamlico Drainage Basin: Albemarle-Pamlico Estuarine Study Project No. 91-08, 54 p. 
Krummel, J.R., Gardner, R.H., Sugihara, G., O'Neill, R.V., and Coleman, P.R., 1987, Landscape patterns in a disturbed environment: Oikos, v. 48, p. 321-24.

Landres, P.B., Morgan, P. and Swanson, F.J., 1999, Overview of the Use of Natural Variability Concepts in Managing Ecological Systems: Ecological Applications, v. 9, No. 4, p. 1179-1188.

Lantis, D.W., Steiner, R., and Karinen, A.E., 1989, California: the Pacific connection: Chico, CA, Creekside Press, 593 p.

League to Save Lake Tahoe (LSLT), 1998, Lake Tahoe Information Center. http://www.tahoe.org/tahoeblue/LakeTahoelnfo.htm

Lillesand, T.M., and Kiefer, R.W., 1994, Remote Sensing and Image Interpretation, $3^{\text {rd }}$ ed: New York, NY, Wiley \& Sons, Inc., 750 p.

Loeb, S.L., 1988, Evidence of land use impacts on water quality within the Lake Tahoe Basin, in Conservation District, p. $25-41$.

Loeb, S.L., Goldman, C.R., 1979, Water and nutrient transport via ground water from Ward Valley into Lake Tahoe: Limnologic Oceanographer, v. 26 (6), p. 1146-1154.International Watershed Symposium [Proceedings], South Lake Tahoe, CA, Tahoe Resource

Lorenz, D.L., and Stoner, J.D., 2001, Sampling design for assessing water quality of the Red River of the North Basin, Minnesota, North Dakota, and South Dakota, 1993-1995. http://mn.water.usgs.gov/redn/rpts/map rpt/map rpt.htm

Mattikalli, N.M., and Richards, K.S., 1996, Estimation of surface water quality changes in response to land use change: application of the export coefficient model using remote sensing and geographical information system: Journal of Environmental Management, v. 48, p. 263-282.

McCarthy, E., 1997, Lake Tahoe: a watershed management study: Western Water, July/August, p. 4 -13.

McClintock, K.A., Harbor, J.M., and Wilson, T.P., 1995, Assessing the hydrological impact of land use change in wetland watersheds: a case study from Northern Ohio, USA, in Geomorphology and Land Management in a Changing Environment, Wiley and Sons Ltd: McGregor, D.F.M and Thompson, D.A., eds., p. 107-119.

McGarigal, K., 2001, About landscape change: http://www.innovativegis.com/products/fragstatsarc/aboutlc.htm (March 16, 2001).

McGarigal, K., and Marks, B.J., 1994, FRAGSTATS: spatial pattern analysis program for quantifying landscape structure, Gen. Tech. Report PNW-GTR-351, USDA Forest Service, Pacific Northwest Research Station, Portland, OR.

McGurk, B.J., and Davis, M.L., 1996, Camp and Clear Creeks, El Dorado County: chronology and hydrologic effects of land use change: in Status of the Sierra Nevada: Sierra Nevada Ecosystem Project final report to Congress, D.C. Erman, ed.: Davis, CA, Centers for Water and Wildlands Research, v. 2, p. 1369-1406.

McMahon, G. and T.F. Cuffney, 2000, Quantifying urban intensity of drainage basins for assessing stream ecological conditions, revised paper for the Journal of the American Water Resources Association, $30 \mathrm{p}$.

Merrill, A.G., 2001, Variation in the structure and nitrogen dynamics of mountain riparian zones: Dissertation for Wildland Resource Science, UC Berkeley, California. 
Mladenoff, D.J., White, M.A., Pastor, J., and Crow, T.R., 1993, Comparing spatial pattern in unaltered old-growth and disturbed forest landscapes: Ecological Applications, v. 3., no. 2, p. 294-306.

Murphy, D.D., and Knopp, C.M., eds., 2000, Lake Tahoe Watershed Assessment, v. 1 and 2: Albany, CA, Pacific Southwest Research Station, Forest Service, U.S. Department of Agriculture, 407 p.

Nautilus project at University of Connecticut, 2000, Characterization of urban sprawl. http://www.resac.uconn.edu/research/sprawl.htm

National Oceanic and Atmospheric Administration, Coastal Services Center (NOAA-CSC), 1995, NOAA Coastal Change Analysis Program (C-CAP): guidance for regional implementation: NOAA Technical Report NMFS 123.

Nevada Division of Water Planning (NDWP), 1997, Truckee River chronology: a chronological history of Lake Tahoe and the Truckee River and water issues. http://www.state.nv.us/cnr/ndwp/truckee/trchrono.htm

Omarzu, T., 1999, Tahoe National Forest established in 1909: Truckee Sierra Sun, p. 9A.

0’Neill, R.V, Krummel, J.R., Gardner, R.H., Sugihara, G., Jackson, B., Indices of landscape pattern: Landscape Ecology, v. 2, p. 6369.

Pielou, E.C., 1975, Ecological Diversity: New York, Wiley-Interscience.

Prisloe, S., Lei, Y., and Hurd, J., 2001, Interactive GIS-based impervious surface model: ASPRS 2001 Annual Convention, St. Louis, Missouri, April 23-27, 2001 [Proceeedings].

PRISM Precipitation Maps: 1961-1990. http://www.wrcc.dri.edu/precip.htm

Reuter, J., Heyvaert, A., and Goldman, C.R., 1997, Historical reconstruction of watershed response to natural and anthropogenic stress: http://ice.ucdavis.edu/cehr/c2c7-8.htm

Richards, L.R., 1999, An historical geographic information system for Truckee, California: Chico, Calif., Chico State University, Master's thesis, $135 \mathrm{p}$.

Riitters, K.H., O’Neill, R.V., Hunsaker, C.T., Wickham, J.D., Yankee, D.H., Timmins, S.P., Jones, K.B., and Jackson, B.L., 1995, A factor analysis of landscape pattern and structure metrics: Landscape Ecology, v. 10, p. 23-39.

Rothman, H.K., 1998, Stumbling toward the millenium: tourism, the postindustrial world and the transformation of the American West: California History, v. 77, no. 3, p. 140-155.

Rowe, T.G., 1999, Comparison of water quality for upstream and downstream sites in the Incline Creek watershed, Lake Tahoe Basin, Nevada, 1990-98, in Western Snow Conference, 67 ${ }^{\text {th }}$, South Lake Tahoe, Calif., April 19-22 [Proceedings], p. 35-44.

1998, Loads and yields of suspended sediment and nutrients for selected watersheds in the Lake Tahoe Basin, California and Nevada, in National Water-Quality Monitoring Council's National Monitoring Conference: Critical Foundations to Protect our Waters, Reno, Nev., July 7-9 [Proceedings, v. 3], p 525-535. 
Rowe, T.G., and Allander, K.K., 2000, Surface and ground-water conditions in the Upper Truckee River and Trout Creek watersheds, July-December 1996, South Lake Tahoe, California: U.S. Geological Survey Water-Resources Investigations Report 00-4001, $39 \mathrm{p}$.

Rowe, T.G., and Stone, J.C., 1997, Selected hydrologic features of the Lake Tahoe Basin, California and Nevada: U.S. Geological Survey Open-File Report 97-384, 1 p.

Scott, E.B., 1957, Saga of Lake Tahoe, v. 1: Filmer Brothers, San Francisco.

Sierra Business Council, 2000, Sierra Nevada Wealth Index: 1999-2000 update: Sacramento, Calif., Sierra Business Council, 124 p. 1999, Planning for prosperity: building successful communities in the Sierra Nevada: Sacramento, Calif., Sierra Business Council.

1996, Sierra Nevada Wealth Index: Understanding and tacking our region's wealth: Sacramento, Calif., Sierra Business Council, $48 \mathrm{p}$.

Sleavin, W.J., Civco, D.L., Prisloe, S., and Giannotti, L., 2000, Measuring impervious surfaces for non-point source pollution modeling: University of Connecticut Laboratory for Earth Resources Information Systems.

Smith, J.L., Stone, J.C., Rowe, T.G., and Gardener, J.V., 1999, Selected hydrologic features of the Lake Tahoe Basin, California and Nevada, 1998: U.S. Geological Survey Water-Resources Investigations Report 99-4031, 1 p.

Sullivan, M., Warwick, J.J., and Tyler, S.W., 1996, Quantifying and delineating spatial variations of surface infiltration in a small watershed: Journal of Hydrology, v. 181, p. 149-168.

Stacey, P.B. and Taper, M., 1992, Environmental variation and the persistence of small populations: Ecological Applications, v. 2., no. 1, p. 18-29.

Tahoe Regional Planning Agency (TRPA), 1988, Water quality management plan for the Lake Tahoe region, v. 5.

1996, Water quality report for the water year 1995.

1999, Regional plan for the Lake Tahoe Basin; Code of Ordinances, Rules of Procedure.

Tracy, J., Bernknopf, R.L., Forney, W.M., and Hill, K., 2000, A prototype for understanding the effects of TMDL standards: tying property values to sediment loads in the Lake Tahoe Basin, in Watershed Management Conference, American Society of Civil Engineers [Proceedings].

Truckee-Donner Historical Society (TDHS), 1994, Fire and Ice, A Portrait of Truckee: Truckee, CA, Truckee-Donner Historical Society.

Turner, M.G., 1989, Landscape ecology: the effect of pattern on process, Annual Review of Ecological Systematics, v. 20, p. 171197.

Turner, M.G., and Ruscher, C.L., 1988, Changes in the spatial patterns of land use in Georgia: Landscape Ecology, v. 1, p. $24-251$. 
Twiss, R.H., Elford, C.R., James, J.W., Mueller, P.K., Smith, K.C., Warburton, J., and Woo, H.W., 1971, Climate and air quality of the Lake Tahoe region: South Lake Tahoe, CA, Tahoe Regional Planning Agency and U.S. Forest Service, 31 p.

U.S. Forest Service (USFS), 2000, Land cover monitoring program. http://frap.cdf.ca.gov/projects/change detection/changedetectfr.htm

U.S. Forest Service (USFS), 2000, Sierra Nevada Conservation Framework. http://www.r5.fs.fed.us/sncf.htm

U.S. Geological Survey (USGS), 1999, High-resolution land use and land cover mapping: U.S. Geological Survey Fact Sheet FS 189$99,2 \mathrm{p}$.

1997, USGS to coordinate online scientific database for Tahoe Basin: press release. http://www.usgs.gov/public/press/public affairs/press_releases/pr376m.html

U.S. Geological Survey (USGS), 2001, Lake Tahoe Data Clearinghouse (LTDC). http://blt.wr.usgs.gov/

University of California, SNEP Science Team and Special Consultants, 1996, Sierra Nevada Ecosystems: in Status of the Sierra Nevada: Sierra Nevada Ecosystem Project final report to Congress, v. 1, p. 6-16.

Urban, D.L., and Smith, T.M., 1989, Microhabitat pattern and the structure of forest bird communities: American Nature, v. 133, p. 811-829.

Urban, D.L., 1999, Using model analysis to design monitoring programs for landscape management and impact assessment: Ecological Applications, v. 10, no. 6, p. 1820-1832.

Walker, D.A., Webber, P.J., Binnian, E.F., Everett, K.R., Lederer, N.D., and others, 1987, Cumulative impacts of oil fields on northern Alaskan landscapes: Science, v. 238, p. 757-761.

Weller, D.E., Jordan, T.E., and Correll, D.L., 1997, Heuristic models for material discharge from landscapes with riparian buffers: Ecological Applications, v. 8, no. 4, p. 1156-1169.

Whitley, M.G., 2001, Digital Lake Tahoe Basin Management Unit GIS Library, South Lake Tahoe, CA, US Forest Service.

Wilkie, D.S., and Finn, J.T., 1996, Remote sensing imagery for natural resources monitoring: New York, NY, Columbia University Press, $295 \mathrm{p}$.

Williams, M.W., Melack, J.M., 1991, Solute chemistry of snowmelt and runoff in an alpine basin, Sierra Nevada: Water Resources Research, v. 27 (7), p. 1575-1588.

Wilson, D., 1992, Sawdust Trails in the Truckee Basin: A History of Lumbering Operations 1856-1936: Nevada City, CA, Nevada County Historical Society.

Wollenberg, C., 1985, Golden Gate Metropolis: Perspectives on Bay Area History: Berkeley, CA, University of California Institute of Governmental Studies. 